\title{
EVALUATING THE FLIPPED CLASSROOM MODEL THROUGH THE MULTI-COMPLEMENTARY APPROACH
}

\author{
Dr. Tarik TALAN \\ ORCID: 0000-0002-5371-4520 \\ Faculty of Engineering and Natural Sciences \\ Gaziantep Islam Science and Technology University \\ Gaziantep, TURKEY \\ Dr. Veli BATDI \\ ORCID: 0000-0002-7402-3251 \\ Gaziantep Education Faculty \\ Gaziantep University \\ Gaziantep, TURKEY
}

Received: 10/10/2019 Accepted: 13/04/2020

\begin{abstract}
This study was carried out to determine the effectiveness of the Flipped Classroom Model (FCM) in an educational setting. For this purpose, a multi-complementary approach (MCA) was used including both quantitative (meta-analysis) and qualitative (thematic). MCA consists of three parts, the first of which is the pre-complementary information stage. In this context, the data from sixty-four studies were used and it was analysed using CMA and MetaWin software. In addition, the meta-thematic data were obtained by analysing thirty-two qualitative studies of FCM and analysed through content analysis. In the second stage of the MCA, an experimental process took place involving the implementation of FCM. A thematic dimension was added to the second stage and analyses were made through MAXQDA software. In the last stage of the approach, the results of the first two stages were combined to get complementary and general outcomes. The results of the study showed that FCM had a positive impact on academic success in general, thus some recommendations were presented on the use of both FCM and MCA.
\end{abstract}

Keywords: Flipped classroom model, multi-complementary approach, meta-analysis, meta-thematic analysis, academic achievement.

\section{INTRODUCTION}

In recent years, there has been a change observed in the education system, with a move from a teachercentred behavioural approach towards a student-centred and constructivist approach in which the student is an active participant. The main purpose of this change can be expressed as the student accessing information on his/her own rather than the direct transfer of knowledge from the teacher to the student. The change also relates to the assimilation of knowledge by the student, that is, the structuring and development of knowledge. In this period of change, the student structures information, makes it meaningful, and integrates it with new experiences that allow him/her to participate actively in the learning process. This increases the permanence of learning.

Changes and developments in teaching methods and techniques are also experienced in terms of educational technologies. Educators and researchers who want to use these technologies effectively in an educational setting have started to implement many teaching methods involving the integration of technology into education, supported by the continuing development of such technology. Although not a new concept, FCM is one of these which has been discussed in the context of the blended learning approach, and frequently mentioned in recent times. This learning model, which is a technology-based teaching model, is defined as the application of learning activities such as recollection and comprehension at home, usually online, unlike the traditional ways of learning, and the implementation of high-level learning practices 
such as application, analysis, evaluation and creation in a classroom environment (Kara, 2016; Mok, 2014; Rutkowski \& Moscinska, 2013). In other words, the transfer of information to the student takes place in the classroom environment, as does the assimilation and retention of knowledge (Bergmann \& Sams, 2012; Hung, 2015; O’Flaherty \& Philips, 2015).

Using technology-supported models and going out of the classroom environment through the use of the FCM has become increasingly important in recent years, and is seen as an alternative to other teaching strategies. Learning is transferred to the individual learning area where students take responsibility for their own learning (Bishop \& Verleger, 2013; Staker \& Horn, 2012). Based largely on the traces of structured learning theory, this model has evolved into a structure whereby the student is active and in the centre, and the teacher is supportive and has the role of guiding and controlling, as opposed to his/her traditional teaching role (Aydin, 2016; Talan, 2018). In addition, as the teaching model moves outside the classroom in this learning model, the time and space limitations in teaching are eliminated and, by providing the opportunity to revisit the subject without limits, students are able to come to class prepared for the lesson (Enfield, 2013; Talan, 2018; Thoms, 2012). In the time spent in the classroom, which is extremely valuable in FCM, practices and collaborative activities are carried out as a result of which knowledge retention is reinforced, and deficiencies are eliminated. Therefore, this learning model does not eliminate the education process in the classroom; rather, it establishes cognitive bridges between the in-class process and the outof-class process, and ensures an uninterrupted execution of the learning process. In this respect, the main purpose of this learning approach, which is appropriate for today's education, can be expressed as the effective and efficient use of the time spent in the classroom (Bergmann \& Sams, 2012; Johnson, 2012; Roehl et al., 2013; Tucker, 2012).

FCM supports the goal of combining online learning environments with traditional teaching methods, combining and blending the strong and advantageous aspects of both, and thus making learning more meaningful. FCM is a pedagogical approach which suggests that the student should learn the contents of the course during out-of-class time, while engaging in discussion, problem-solving, implementation, projectbased study and thus engaging in active learning during the time in the classroom (Bergmann \& Sams, 2012; Johnson, 2012). When we look at the studies conducted on this model, we can see that different tools, methods, practices and approaches are used. However, the features highlighted in the definitions related to FCM are that the model is student-centred, supports effective learning, increases the quality of in-class study time, provides a richer and more flexible learning environment with the technological infrastructure it offers, and is a component of blended learning.

Characteristics such as ensuring students coming to class are prepared in advance, allow interactive and practice-oriented learning, increase teacher-student interaction, allow the active participation of students in the lesson, provide opportunities for teacher guidance, contribute to the development of the self-regulation and self-efficacy of students, and can be seen as the positive aspects of FCM (Bishop \& Verleger, 2013; Bosner et al., 2015; Enfield, 2012; Halili \& Zainuddin, 2015; Rutkowski \& Moscinska, 2013; Sirakaya, 2015; Talan \& Gulsecen, 2018). In addition, supporting individual and self-learning at the student's own pace, creating time for active learning activities, encouraging the learner to take responsibility for his/her own learning, allowing collaboration, question-answer and discussion activities, can all be expressed as the other positive aspects of the model (Bergmann \& Sams, 2012; Bishop \& Verleger, 2013; Chen et al., 2014; Chu $\&$ Sun, 2015). In addition, this model allows the use of rich and accessible materials, and enables the creation of permanent learning outcomes (Mason et al., 2013; Turan, 2015). Morgan (2014) also stated that the model contributes significantly to the institution's economic situation by reducing the running costs of educational institutions.

In contrast to these positive aspects provided by FCM with regard to teachers and students, there are also some studies that indicate that there are a number of disadvantages and limitations. These include not having access to technological tools such as computers and the internet for each student, the difficulty of determining whether or not students watch videos, and technical problems experienced during the application can be some of the disadvantages of the model (Aydin, 2016; Bergmann \& Sams, 2012; Enfield, 2012; Fraga \& Harmon, 2014; Milman, 2012; Yavuz, 2016). In the literature, it is also stated that, if a student is unable to ask questions immediately s/he does not understand the theoretical part of a lesson at home, this may lead to an interruption in the student's learning process (Talan, 2018; Turan, 2015). In addition, the lengthy 
and poorly prepared video lessons have been shown by researchers to reduce the motivation of students and reduce their interest (Kara, 2016; Milman, 2012; Yavuz, 2016).

When the literature on FCM is examined, there are studies that indicate that the model increases success in many areas such as social sciences, foreign languages, science, mathematics, health sciences and engineering (Alamri, 2019; AlJaser, 2017; Atwa et al., 2016; Aydin, 2016; Bulut, 2018; Cakir, 2017; Elian \& Hamaidi, 2018; Sirakaya, 2015; Thai et al., 2017; Yurtlu, 2018), while there are also studies that show that this model does not cause a significant increase in success, or indicates that no significant differences were observed in comparison with other approaches (Davies et al., 2013; Dixon, 2017; Duffy, 2016; Dusenbury \& Olson, 2019; Overmyer, 2014; Voltz, 2016). Encountering differing results in the review of the relevant literature supported the need for carrying out this research. Detailed analysis of FCM was carried out in this research by conducting a meta-analysis and meta-thematic analyses. Using the results obtained, an attempt was made to determine the extent to which FCM has an impact on success.

\section{MULTI-COMPLEMENTARY APPROACH (MCA)}

It was thought that this concept encountered in the related body of literature (Bamberger, 2012; Barg et al., 2006; Fink, 2013; Gilgun, 1999; Krathwohl, 1993; Laundry \& Banville, 1992; Morse \& Chung, 2003; Palak \& Walls, 2009; Reich, 2010; Schiffman, 1990; Trochim, Marcus, Mâsse, Moser \& Weld, 2008) as a multi/integrated approach (multi-method/mixed method approach/methodological pluralism/integrated approach) does not exactly correspond to the concept adopted in the present study. For instance, certain studies at international area were recorded to conduct mixed method (Esteves \& Pastor, 2004; Onwuegbuzie \& Dickinson, 2008), however, they were strucruted in a different way and also the final target is not in the same direction. Hence, in accordance with the MCA approach used in the present study, the single data source is not considered sufficient, the results need detailed explanation and the study is expected to include many stages. Therefore, the use of the concept of "multi-complementary approach" based on the combination of all the results was preferred. In this way, the presentation of both qualitative and quantitative data is possible. In addition to the qualitative method, which comprises the conduct of studies based on sample groups, and which therefore has the quality of being generalizable, the addition of quantitative methods, which have fewer samples but which enables more detailed studies, may contribute to the formation of qualified and extensive studies. On the other hand, it may be indicated that the word "complementary" in the multicomplementary approach gives new meaning to this concept. The difference in terms of this concept, which is actually based on the Gestalt holistic approach is that it provides the presentation of research results obtained in various ways (through different analytical programs involving both qualitative and quantitative data sources) by gathering them under a single roof. Therefore, it is accepted that the concept "multicomplementary" actually serves to explain the new orientation considered, in terms of its lexical meaning.

When the details of the multi-complementary approach are examined, they may be interpreted as the gathering of data accessed through different methods and programs dealing with a common area of interest. In this stage, a multi-complementary approach may be based on constructivist learning theory, the pioneers of which are Piaget, Bruner, Vygotsky, Dewey, Gestalt and Glasersfeld. In research into a topic based on this theory, the interest is in accessing new information by integrating such information with old information. Consequently, the existing information regarding that topic should be accessed by the student. This matter is crucial regarding the authenticity and the originality of the present research. Thus, in the relevant research identified in the body of the literature, analyses involving the examination of the present situation were performed, and no research aimed at determining the shortcomings related to the topic was found. Besides, another aspect of the complementary approach that coincides with the constructivist approach are the opinions of Vygotsky, Bruner, Gestalt and Dewey which are based on pragmatic philosophy. These famous thinkers stated that life is constantly changing, and therefore there is a need to restructure everything. This view is the main basis of the study. Therefore, the individual may not be able to use the information $s /$ he has obtained previously throughout his/her social life, both because the event and situation and the individual him/herself has changed, and may need to reconstruct the information. Thus, the individual forms new schemes, theories and experiences regarding the changing information, and integrates them with the previous ones. The individual who has new experiences forms new schemes and theories, and this process 
is constantly repeated. However, at this point, the important thing for the individual who is faced with new information, in other words who becomes unbalanced, is that s/he identifies the deficiency and mistakes about him/herself, and tries to overcome the problem that has arisen. At this point, understanding that what is important in terms of education is the way to obtain information rather than the information itself becomes apparent (Sonmez, 2008). Therefore, it may be indicated that the multi-complementary approach, which is explained within the scope of this study, and regarding which there is an effort to create awareness, is a crucial and necessary issue, because it is a new approach that deals with how the information aimed at in scientific studies is obtained. At this point, in academic studies, the approaches and methods used while accessing information have to be renewed, and different and creative ideas such as the multi-complementary approach have to be actualized.

Within the scope of this approach, the main aim in the integration of data obtained from different sets of information in order to achieve a whole is to access extensive, qualified, scientific and complementary information. This situation necessitates certain processes. The process concerned is explained in detail in the methods part. On the other hand, the primary aim of the study in terms of a multi-complementary approach is to proceed based on the subgoals of the research concerned in order to achieve the whole. To put it a different way, the complementary scope of the study that ise thought to be achieved is determined by the subgoals of the related research.

\section{THE PURPOSE AND SIGNIFICANCE OF THE RESEARCH}

In this study, it was decided to use a multi-complementary approach (MCA), which is not found much in the literature regarding the FCM in a form which includes detailed analyses and evaluations. In order to examine the effectiveness of the FCM in all aspects of the literature, and to reflect on its relationship with success, a detailed analysis like this was required. When the literature on FCM was reviewed, it was found that the existing studies were one-sided, narrow in scope, and without detail. At this point, the aim was to investigate the FCM extensively through the use of the MCA which allows detailed and multiple analyses. The MCA used in the research involved three basic stages. In the first stage, the aim was to review the literature on the topic under consideration and to obtain the pre-complementary information that reflects the existing deficiencies; in the second stage, the aim was to obtain the post-complementary information which includes complementary applications for the elimination of any deficiencies; and, in the final stage, the aim was to obtain complementary information, when the data from both stages are combined and synthesised, and the original ideas and suggestions are presented in this context (Batdi, 2018). It is believed that the results will provide a comprehensive and general overview of the recently-popularised FCM implementations, and that MCA will attract attention in the literature and encourage researchers to conduct studies using these methods. In this study the impact of FCM on academic achievement was examined using studies within the scope of the inclusion criteria, and meta-analytical examinations were carried out with regard to which teaching grades, application process and subject areas the existing studies related to. In addition to quantitative studies related to the effect of the FCM on academic achievement, a meta-thematic analysis that it is a method including the process of reviewing the themes from participants' views of various studies (Batdi, 2019) was conducted, and qualitative findings were obtained. In this respect, it is thought that the contribution of this study to the relevant literature will be original, and that it will contribute to the effective evaluation of the model. In this context, the main purpose of the research is to examine the FCM in the context of the MCA. The research questions that need to be answered in line with this basic objective are as follows:

\section{First stage: in order to obtain pre-complementary information;}

a. Through document analysis-oriented meta-analytical studies, what is the effect size/effect of FCM on academic achievement?

b. How effective is the FCM in the context of thematic analysis based on document analysis?

\section{Second stage: in order to obtain pre-complementary information;}

a. Is there a significant difference between the pre- and post-test scores of students academic achievement related to FCM?

b. What are the views of participants on the effectiveness of the FCM in a qualitative context? 


\section{Third stage: in order to obtain complementary information;}

a. Using the MCA, are the overall results obtained, after combining pre- and post-complementary information, complementary?

b. In view of the results obtained, what are the recommendations on the subject with regard to the use of the FCM?

\section{METHOD}

This study was carried out to determine the benefits of the FCM in an educational setting and its effectiveness with regard to learning. In order to examine all aspects of FCM, to conduct detailed analyses, and to provide a comprehensive perspective, a wider perspective was required in terms of the method followed. In this respect, it was decided to carry out the research in accordance with the MCA used in the studies by Batdi (2018). MCA is an approach based on a combination of various analyses programs, rich data sources and findings obtained through the use of complementary approaches. There is a system that ensures the systematic and orderly operation of this multi-faceted methodological approach. Specifically, the MCA consists of three basic stages, which allow access to pre-complementary, post-complementary and complementary information (Batdi, 2018). These steps are presented below (Figure 1):

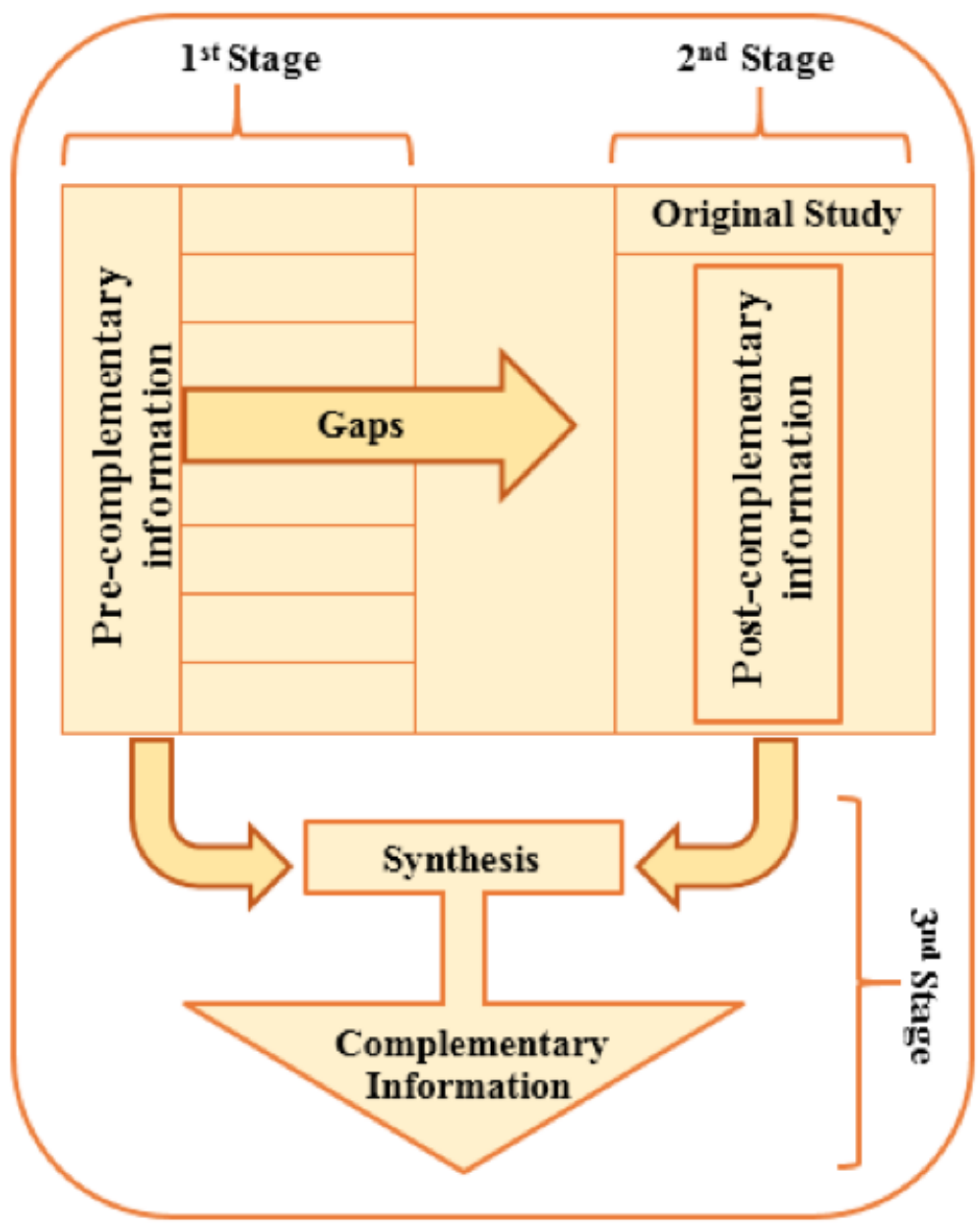

Figure 1. Multi-complementary approach model (Batdi, 2018) 


\section{Pre-complementary Information Stage}

During this stage, which constitutes the basis of the study, previous studies on the subject are examined using different methods such as meta-analysis, with the aim being to determine the existing deficiencies on the subject (Batdi, 2018). At this stage, the primary objective is to determine the area (period, type of publication, working year, subject area, teaching stage and sample size) that the chosen research covers in the related body of literature. It may be maintained that the data accessed will form the source and basis of the post-complementary stage in the second stage. In this context, meta-analytical and thematic methods were used to obtain pre-complementary information for FCM. In a sense, the meta-analysis, which can also be referred to as document analysis or analysis of analyses (Glass, 1976), is described as a concept which includes a systematic integration of previous research on the same subject which expands the scope by obtaining large samples and, consequently, provides a stronger and more general judgment (Cumming, 2012). At this point, various databases were examined in terms of the academic achievement dimension in order to obtain relevant studies on the FCM.

\section{Literature Search and Inclusion Criteria}

In this context, Google Scholar, Academic Search Complete, Education Research Complete, ProQuest Dissertations and Theses Global, ERIC (EBSCO), Springer LINK, Wiley Online Library Full Collection, Science Direct, Higher Education Council (HEC) National Thesis Center, the Web of Science and Scopus (A\&I) databases were scanned. "Flipped learning, fipped classroom, inverted learning, inverted classroom" were used as keywords in the search process. As a result of this scanning, a total of sixty-four studies, including thirty-seven dissertations and twenty-seven articles, were included in the meta-analytical study. It is interesting that, in terms of their inclusion criteria, most of the studies chosen were theses. However, when the inclusion criteria, which may ease the integration of the findings and lessen the extreme differences between the studies were considered in line with the targets of the research, this was the result. Besides, there is also a national thesis center based in Turkey, where access to Master's and $\mathrm{PhD}$ theses on the internet is possible. In this the Higher Education Council of National Thesis Center - the theses can be archived by the authors of the related database, opened to full-text access over the internet, and submitted for open access. Therefore, the studies accessed through this database relating to the FCM were included in the analysis within the context of inclusion criteria. In some studies, because the effect of the FCM on academic achievement was calculated separately for different courses/classes, the data set was determined as totalling seventy-one items. In metaanalysis studies, in the event of the inclusion of poor-quality studies in the analysis, a situation occurs whereby it is expected that errors will be reflected in the research (Borenstein et al., 2009). Thus, the authors acted in conformity with the inclusion criteria in the meta-analysis, both in order to prevent this situation, and to reduce the number of studies.

Therefore, in the selection of these studies, the criteria, which include descriptive data [sample size (n), arithmetic mean $(\overline{\mathrm{X}})$ and standard deviation (SS)] used to examine academic achievement and to calculate the effect size, were taken into consideration. The studies must employ an experimental or quasi-experimental design in which there is a comparison between the use of the FCM and traditional methods. Therefore, this research consists of scientific studies conducted on the use of the FCM. The sample of the study consists of selected studies from theses and articles obtained from the above-mentioned databases between 2013 and 2019, taking into consideration the inclusion criteria.

\section{Selection of the Studies}

The reason for the selection of the period between 2013 and 2019 for consideration is the increased prevalence of studies related to the use of the FCM after 2013. Since the paper and congress abstracts did not include adequate statistical data for meta-analysis purposes, they were not included in the analysis. When the search was undertaken was undertaken, titles and abstracts were first read to be sure that the studies were related to the use of FCM. As part of this process, the related documents were saved in a folder while the others were excluded. 350 studies were accessed following the search. It was seen that 89 of the studies accessed were included only as a title, and that the content was not in compliance with the topic of the research. 
The decision was therefore made to eliminate them. In the second stage, in the evaluation made regarding convenience, it was decided that 92 of the remaining 261 studies were not appropriate in terms of the aim of the research, and the decision was made to eliminate them. In terms of traditional applications, studies which did not comprise a comparison of the FCM and the success levels of students taught conventionally were not compared were eliminated at this stage. In the next stage, it was determined that the results of 28 studies out of 169 were not adequately presented, that the scores of pre-test and post-tests performed on experimental and control groups were not measured, and these studies were consequently not included in the analysis. Lastly, with 77 studies, it was seen that the statistical data calculated for experimental and control groups were not presented separately, and that these values could not be accessed. It was therefore decided to remove these studies from the analysis. Therefore, 71 effect size comparisons out of 64 studies in total were included (see Figure 2: PRISMA). As in the present study, Cheng et al. (2018) had 55 publications with 115 effect size comparisons they accessed in the meta-analysis study that they conducted on the use of the FCM.

The data obtained in the meta-analysis were analysed using CMA and MetaWin software. The data obtained (meta-analytic) is to be interpreted/discussed according to the effect size classifications of certain pioneers such as Shachar (2002), Cohen, Welkowitz and Ewen, (2000) and Thalheimer and Cook, (2002). In the present study, in terms of the effect size, the classification level of Thalheimer and Cook (2002) was made use of.

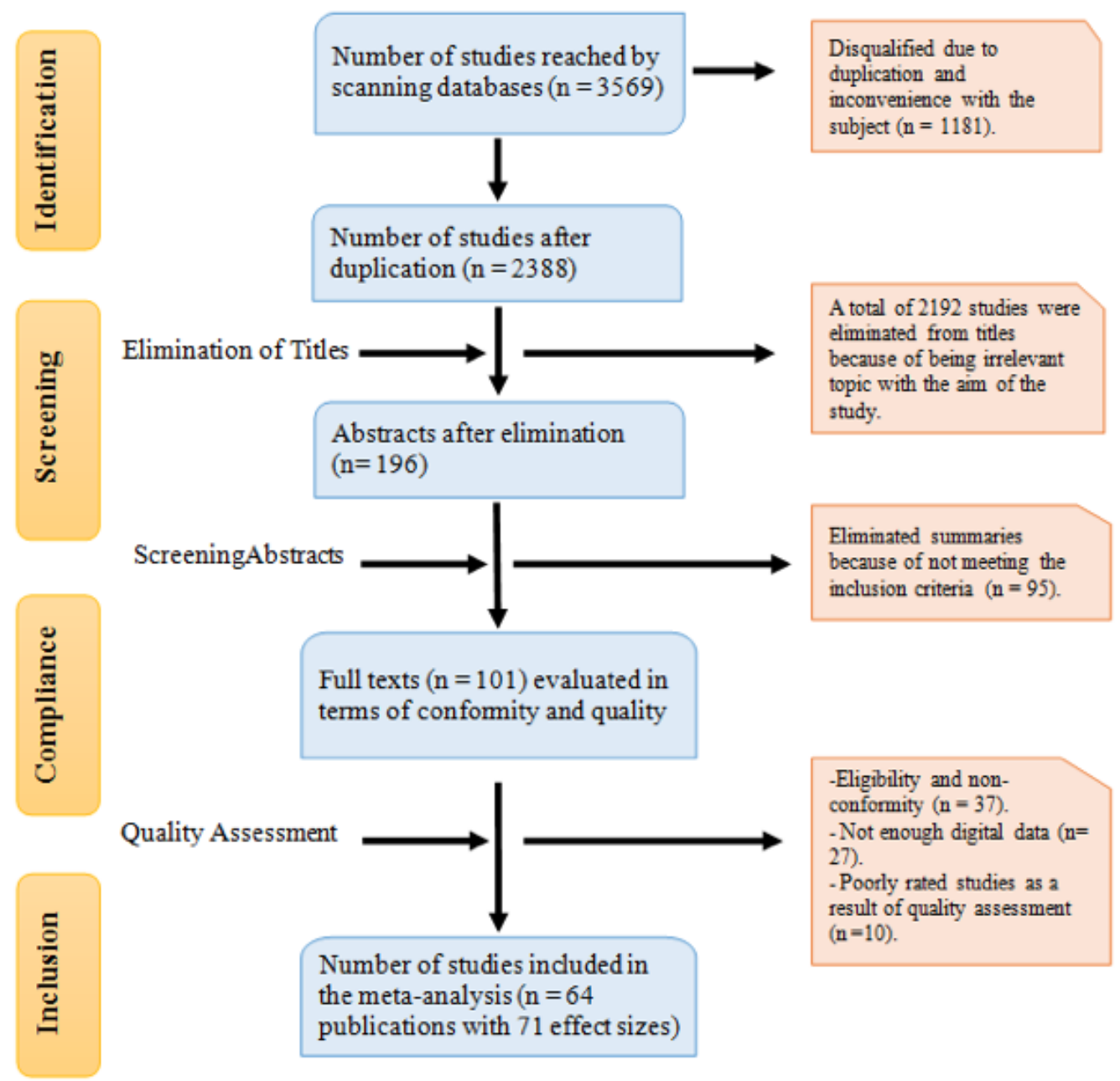

Figure 2. PRISMA flowchart of study selection 


\section{Model Choice}

In the meta-analysis, the effect size within the studies are measured based on two different models. These models were specified as stable and random effects model. However, different operations are performed for the models chosen, their effect sizes and confidence intervals, in accordance with the property of the research. Whereas it is assumed that all the studies in the meta-analysis share a common effect size in the stable effect model, it is accepted that the real effect size may change in different studies in the random effects model (Borenstein et al., 2010). In other words, in cases where real effect calculations are made with limited populations rather than large ones, the stable effects model should be preferred. Especially in the social sciences and the educational sciences, it is almost impossible to find the preconditions necessary for the stable effects model. Hence, in the random effects model it is accepted that the effect size changes in terms of sample groups and studies. It may be maintained that the effect size changes according to the studies under consideration in terms of factors such as age, educational level and class. Therefore, the random effects model is preferred in such situations. In the present study, the analyses were interpreted using the random effects model.

\section{Coding}

In the meta-analysis, the coding operation was performed with the aim of ensuring reliability in the categorization of studies and in the examination of content. Coding is a way of evaluating reliability by revealing the extent of repetition of similar studies as a result of independent efforts. This may also be performed between reliability coders (intercoders) or for the same coder (intracoder) (Wilson, 2009). In the operation conducted between coders, both coders should code studies separate from one another. There is a higher level of authenticity, accuracy and reliability in coding undertaken in this way. In addition, the number of studies should be adequate in order to provide a clearer estimation of reliability throughout the coding process (Card, 2012). Lipsey and Wilson (2001) suggested that it would be adequate if the number of studies is between 20 and 50. A number between these may provide a perception of the interference level of the coding. However, we should also be aware that there are different methods used to measure coding reliability. Three of them take the form of adaptive values, Cohen Kappa or Pearson correlation (Orwin \& Vevea, 2009). In the present study, demographic properties such as the publication type, publication year, author names, the conducted level, sample groups of the studies were scanned to be able to realize coding efficiently. These were coded by forming a table in a Word document. Codes (number and letter) were also given to the studies. Two coders performed the same coding separately. The accord between the codings of the coders was determined. Since the correlation between the coders was stated as the degree of reliability for this purpose, that this correlation was found to be high is interpreted as the safety of using these documents as being high. In the present study, the reliability formula [consensus / (consensus + disagreement) x 100] proposed by Miles and Huberman (1994) was used to calculate inter-rater reliability in the meta-analytical dimension. As a result of this calculation, the reliability of the study was found to be $100 \%$.

\section{Effect Size}

Effect size is a value used to give information about the difference between two groups or the magnitude or aspect of the relationship between two variables (Borenstein et al., 2009) and regarded as a golden measurement in meta-analysis (Rosenthal, 1995). Hedges' $g$ value was used as a measure of the standardized mean difference in order to estimate the effect size values of the studies in the meta-analysis. This value utilizes degrees of freedom to predict the standard deviation collected from two independent groups. There is also Cohen's d value. However, this value is a slightly more prejudiced estimator (Borenstein et al., 2009). At this point, the values considered in the measurement of effect size within the scope of the research were sample size, pre-test mean, pre-test standard deviation, post-test mean and post-test standard deviation. In the present study, Hedges' g value was preferred, both because it uses the less-biased pooled standard deviation, and because it is weighted in line with the the sample size (Hedges, 1982).

There are three major elements which affect the choice of effect size. The first is that the effect sizes obtained from different studies should be compared with each other in given that they measure the same things. In 
other words, effect size should not differ according to the design of the studies (like the sample size or whether common variables are used or not). The second is that effect size estimations should be calculated based on the possible information in the published research reports. In other words, it should not necessitate the re-analysis of raw data. The third issue is that effect size should have good technical characteristics. For instance, sampling distribution should be known so that the variance and confidence ranges can be calculated. Besides, effect size should be interpretable to a large extent. If the effect size is not meaningful naturally, it is generally possible to transform it into another metric for presentation purposes (Borenstein et al., 2009).

\section{Moderator Analysis}

Considering the heterogeneity in effect size, an important aspect of meta-analysis is to understand the reasons why effect sizes differ between studies. For this purpose, continuous variables were used, and a moderator analysis was performed (Kelly, Polanin, Jang \& Johnson, 2015). It was questioned whether effect dimensions change in terms of teaching grades, application period and subject area. Moderator analyses including fewer than five studies were excluded in order to avoid prejudiced results. A random effects model was used to evaluate the moderators.

\section{Publication Bias}

Publication bias poses a threat for the results obtained in the meta-analysis. This is because publication bias is based on the assumption that not all the published works relate to a particular subject. Since studies which have no significant difference or have a weak significance statistically, are not considered appropriate for publication by publishers, it is believed that they have a negative influence on the total effect, or that they are prejudicial to the mean effect size (Kulinskaya et al., 2008). It is thought that this publication bias which may be considered as missing data for a meta-analysis, has a negative influence on the total effect of a meta-analysis. Therefore, publication bias should be considered in meta-analysis studies (Borenstein et al., 2009). There are various methods and ways of improvement with regard to this potential bias. In this sense, consideration of more than one method may reveal a potential bias, which not everyone is aware of. On the other hand, the increase in the amount of proof of possible bias may increase the possibility of achieving satisfactory results (Card, 2012).

As is also indicated in the present research, in terms of the criteria used for the choice of studies included in the analysis, both published and unpublished literature was included in the examination. Thus, Rothstein, Sutton and Borenstein (2006) asserted that the delimitation of studies included in the analysis solely in terms of studies published in refereed journals, raises the possibility of bias. In response to this, unpublished theses were included in the analysis. On the other hand, most literature collecting methods were used, to prevent the possibility that unpublished studies may not be identified because of the dossier drawer problem (Banks, Kepes \& Banks, 2012; Rosenthal, 1991). Articles and theses were accessed online and via databases, and studies were accessed by interviewing the authors, when it came to studies the complete data for which could not be accessed. It is probable that the findings of unpublished studies are less reliable, and are therefore less acceptable (Relman, 1980). Therefore, as mentioned above, with the inclusion of such studies in the analysis, proof of the surfacing of possible bias increases. This, in turn, affects persuasiveness and reliability positively. In the present research, Duval and Tweedie's "trim and fill" method (2000) was used in order to determine bias, in addition to the inclusion of unpublished theses in the analysis.

Based on this method, the point estimation in REM for joint workings and the $95 \%$ confidence interval is 0.46212 . The estimated point value may be determined as 0.21619 , using the "trim and fill" property. It was concluded that the research and scanning processes are valid representations of the study universe, when it was seen that there is a minor difference between the observed and the estimated mean effect sizes. Additionally, fail-safe analysis, and some values in the Normal Quantile plot graph, also presented data regarding the reliability of the meta-analysis process. The Normal Quantile Plot graph shown in Figure 3 represents the range in which the set of dots is located. 


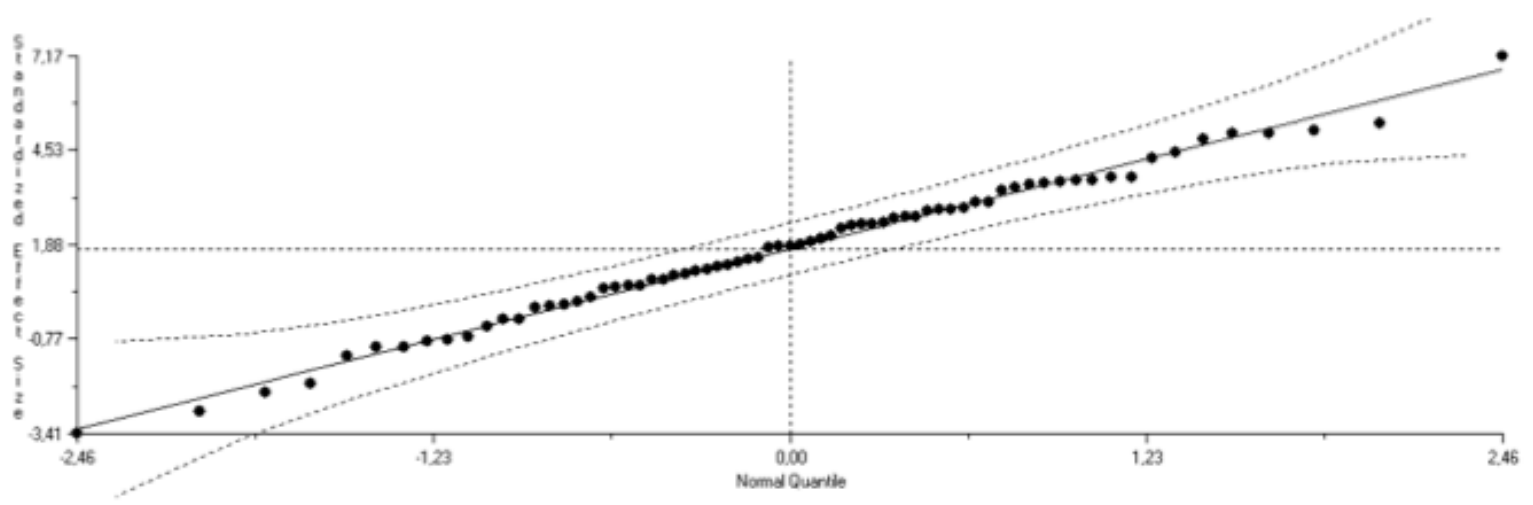

Figure 3. Normal quantile plot

It can be stated that the distribution formed by the set of points in Figure 3 is between the two lines, and the distribution is in the reliable range. Therefore, there is a statistically significant relationship between the studies. Another method by which meta-analysis reliability is evaluated is the calculation of publication bias. Publication bias arises from the inclusion of studies that differ significantly into the analysis, in other words, only when published studies are included in the analysis. At this point, a fail-safe number [fail-safe (FSN)] is calculated, which is considered to minimise or eliminate the publication bias (Rosenthal, 1979). As a result of the analysis conducted in the present study, it was understood that the 5725.2 value for the effect of the FCM on academic achievement would decrease to zero if the study included more analysis. Considering that this value was an extremely high number within the framework of the research, and that too many studies that could not be obtained were needed, it was found that the publication bias had no effect on the significant effect size (Cheung \& Slavin, 2011) and therefore the analytical procedures were quite reliable. The consensus between the classical safe $\mathrm{N}$ test and Normal Quantile Plot graph shows that there is no publication bias that will pose a serious threat to the validity of the meta-analysis. A similar result was also seen following another study conducted on the same topic (FCM) (Cheng, Ritzhaupt \& Antonenko, 2018).

Other methods which complement this information provide access to pre-complementary information and contribute to the internal validity of the research, are thematic (qualitative) investigations. In this context, qualitative studies in the literature on the FCM were reviewed, and thirty-two studies were identified. Studied conducted between the years 2013 and 2019 in both the national and international area, which present qualitative data and which examine the effectiveness of the FCM in terms of academic success and other aspects (personal dimension, learning process, sensory dimension, general contribution, problems and suggestions) were considered. MAXQDA, a computer-aided qualitative data analysis program, was used to analyse these studies. A content analysis method was used to analyse thematic data. This approach, in which data are analysed in depth, is described as accessing concepts and relationships in order to explain the data collected for research purposes (Yildirim \& Simsek, 2013). Since some of the studies identified using these criteria in the body of literature were not deemed adequate in qualitative terms, they were eliminated, and a total of 32 relevant studies were obtained. Firstly, the coding of these studies was provided, and then themes were formed by the combination of codes considered to relate to one another. In this way, a brief presentation of the codes and themes obtained based on the opinions of the contributors was acquired. The studies (which took the form of theses), were coded with their numbers given by the thesis centers (ProQuest Dissertations and Theses Global \& Higher Education Council). The codes given to the studies were presented with the page number cited, while comments were made in the findings part, and examples were given using direct citations. Themes and codes of the studies were cited in the research, and were coded and indicated in the relevant places in the text. For example, the expression 429617-66 refers to Page 66 of study No. 429617. In order to calculate the reliability of the thematic dimension based on document analysis, the agreement values between data encoders (Cohen Kappa) were examined (Viera \& Garrett, 2005). Agreement values calculated for the themes were shown to be between .722 and .868 which indicate that they were at a "good level" (Appendix 1). 


\section{Post-complementary Information Stage}

In the pre-complementary information stage, the information obtained regarding the state of the research topic in the body of the literature involving inductive methods are aimed at determining the deficiency of this topic as a whole. A post-complementary information stage was conducted in order to pursue a new/ original study at the point determined to be deficient/insufficient in line with the state that occurs. This was done in a sense both to take a complementary stage towards the deficiency in this area, and to create an awareness regarding the existence of such a deficiency. In order to determine the impact of the FCM on academic achievement at this stage, teacher candidates studying in the Turkish Language Teaching $(n=30)$ and the Social Sciences Teaching ( $\mathrm{n}=34)$ departments on in an Information Technologies course at a public university located in South Eastern Anatolia in Turkey, were selected as the study group (Table 1). This aspect of the research took place during the fall semester of the 2018-2019 academic year. In this study, different teaching methods were applied to experimental and control groups. Students in the experimental group learned the theoretical part of the lesson at home within the scope of the FCM and participated in active learning activities in the classroom environment. The students in the control group were taught in line with the current curriculum, and the theoretical part of the course was done in the classroom. They then engaged in active learning activities (homework) at home.

In the research, firstly how the lesson will be taught, student responsibilities, access to necessary sources, and determination of the learning outcomes were determined and activities were then planned in detail. Subsequently, an online learning environment was designed to be used solely with the experimental group as part of the application process. Throughout the research, the FCM was used in the case of the experimental group, and traditional face-to-face learning methods were applied in the case of the control group. The figurative appearance of the experimental model used in the qualitative dimension of the research is presented in Table 1.

Table 1. The figurative presentation of the research model

\begin{tabular}{lcccc}
\hline Groups & Neutrality & Pretest & Method & Posttest \\
\hline $\mathrm{G}_{1}$ & $\mathrm{R}$ & $\mathrm{O}_{1.1}$ & & $\mathrm{O}_{1.2}$ \\
$\mathrm{G}_{2}$ & $\mathrm{R}$ & $\mathrm{O}_{2.1}$ & $\mathrm{X}_{1}$ & $\mathrm{O}_{2.2}$ \\
\hline
\end{tabular}

The meanings of the symbols used in the model:

$\mathrm{G}_{1}$ : "Control Group" where the lesson is taught using traditional face-to-face learning methods

$\mathrm{G}_{2}$ : "Experimental group" where lessons are taught with FCM

R: Neutrality in the determination of groups

$\mathrm{O}_{1.1}-\mathrm{O}_{2.1}:$ Pre-test

$\mathrm{X}_{1}: \mathrm{FCM}$

$\mathrm{O}_{1.2}-\mathrm{O}_{2.2}:$ Post-test

As can be seen in Table 1, the study was conducted with two different groups. Before the experimental application, the students sat an achievement test and their knowledge levels were determined. Following the experimental application, the students sat another achievement test and their success in the lessons was determined. The results following the experimental application were evaluated considering the scores of the groups.

In order to measure the achievements of the students and to determine the differences between the achievement levels of the two groups in the study in terms of the pre-test/post-test, semi-experimental research technique with the control group, the reliability and validity analyses which were developed by Talan (2018) were used. An academic achievement test was prepared by taking into consideration the steps of remembering, comprehension and application in terms of Bloom's educational goals. Other steps related to Bloom's educational goals were carried out with regard to the students in the Information Technologies course, mainly through classroom practice and evaluation activities. In this study, the discrimination index of the success test developed was calculated as 0.45 and the mean difficulty value as 0.49 . In addition, the KR-20 coefficient of the test was calculated as 0.805 . The SPSS-18 package program was used in the statistical analysis of the data obtained with regard to the achievement test. 


\section{Operation Process}

In the study, different teaching methods were applied on the experimental and control groups. The students in the experimental group learned the theoretical part of the lesson at home within the scope of the DSM and then took part in active learning activities in a classroom environment. The students in this group received different types of educational material (an e-book, video lectures) prepared in relation to the content of the lesson. Using the tools available they had internet access to the theoretical part of the lesson prior to the classroom session through learning management systems. They wrote their thoughts about online and face-to-face courses via forums, and discussed any topics they did not understand. Therefore, each student took part in the lesson by sharing information through forums and through student-student and studentinstructor interaction, and they also communicated out of the classroom. In additiopn, every week a mini exam application was made use of regarding the topic under consideration in order to motivate the students about studying before the class, and testing the effectiveness of the course resources. The student who has completed this exam and achieved an adequate level of learning ends the self-learning process regarding the topic. The students in this group were able to ask questions about the topics they did not understand at the beginning of the lesson. In the next stage, the students proceeded by discussing the answers to the mini exams and the related topics of the lesson was taught again. It was determined whether or not there were problematic points through this exam. The instructor performed a mini-presentation of the topic when needed. The issues regarding which confused the students minds were misunderstood by them, were corrected through student discussion, and the intervention of the instructor was almost unnecessary. Accordingly, in the classroom environment, the related activities prepared aimed at a high level of learning on the part of the students were realized in company and under the guidance of the instructor, individually or as a group. Since the time issue has to be measured correctly in the FCM, care was taken not to give the activities as homework and to practice and finalize these activities in the classroom environment. Following the activity, the topics not learned by the students were repeated, and the instructor summarized the topic. The planned format regarding the DSM is as follows:

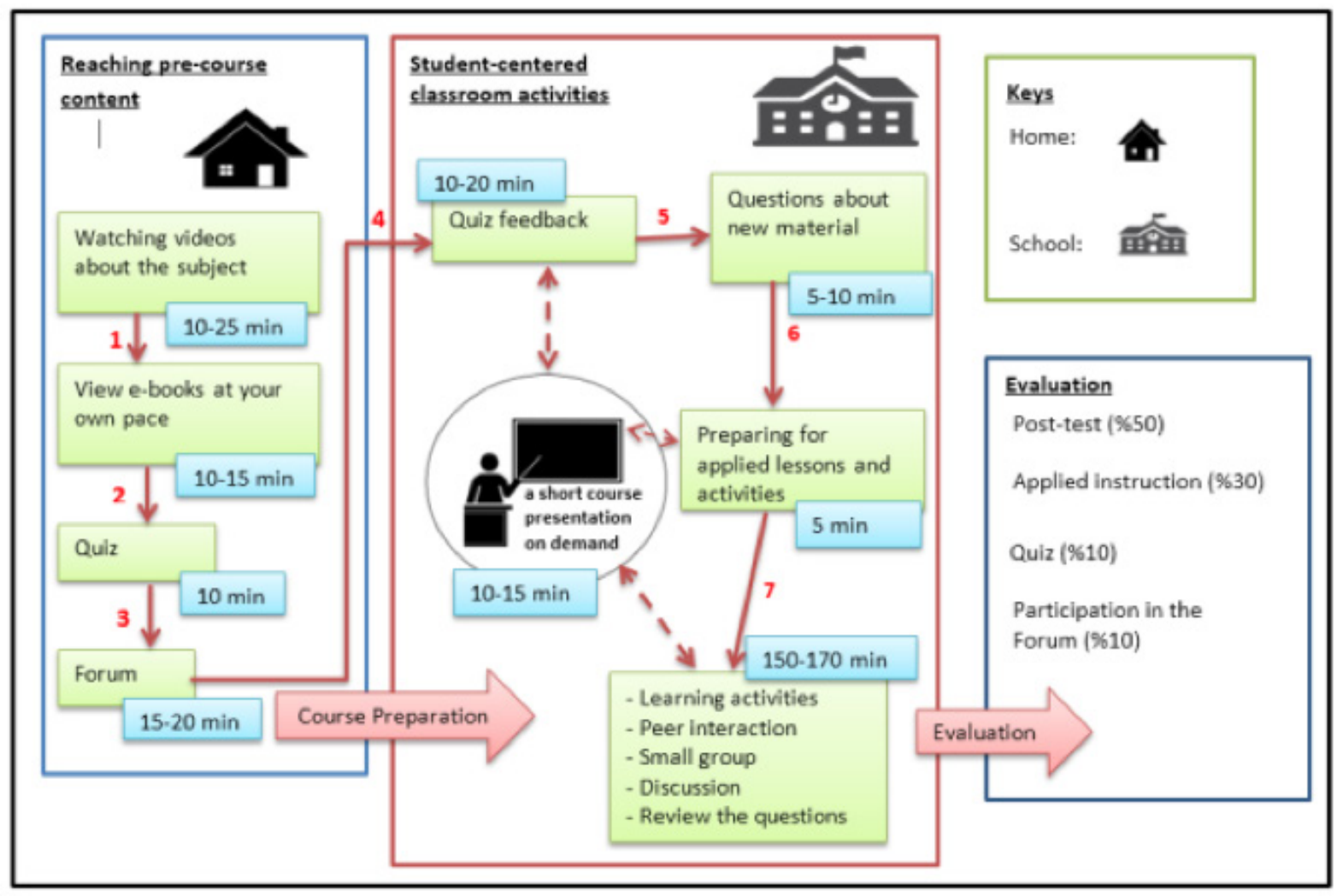

Figure 4. Flipped classroom design (Talan \& Gulsecen, 2019) 
Since the self-learning and the learning speeds of the students in this group are important, individual students may follow the course content according to their learning speed in any place and time that they like, and to the extent that they find necessary. Each student's system record was examined in order to be sure that s/he watched the video lessons. Students were asked to follow the course contents before coming to the class and to be prepared when they arrived. The students who came to the lesson unprepared were given the chance to follow the course contents before joining in the classroom activities. Care was taken to ensure that video lesson periods were between 10 and 25 minutes, in line with the content of the lesson and the property of the topic, in order to pursue the success of the application and to be accepted by the students. Even though we assume that students can constantly access online materials, the downloading of the weekly course materials (the e-book) and their presentation was done in such a way that they can be printed out. The lesson was taught in line with the curriculum to the students in the control group, and the theoretical part of the lesson was practiced in the classroom; it was ensured that they practiced the active learning activities (in the form of homework) at home. At the beginning of the lesson, the instructor gave the students feedback regarding the activities (homework) of the previous week, and ensured that any deficiencies were remedied. In line with the baby steps principle, the instructor, without any preliminary preparation on the part of the students, presented the topic hierarchically to the students. The content of the topic was presented using traditional methods such as direct instruction, presentation, and question-answer. In the next stage, a mini-exam application was made regarding the topic, and afterwards the teacher provided feedback to the questions. The questions which the students had problems with were answered, and the topics that were not understood or were misunderstood, were corrected. In the remaining time, there was an effort to form an infrastructure regarding the content of the lesson in the computer lab, and sample educational applications aimed at training/ reinforcement were made to help the topic become more distinct and permanent in the students' minds. The points with regard to which learning was not realized were repeated at the end of each lesson, and the topic was summarized by the instructor. The activities (homework) prepared to encourage high-level learning were shared physically (in the form of a printed photocopy) and were realized in out-ofclass activities. The delivering of the activities was realized at the end of a one-week period by hand (usb flash memory) in the classroom environment. The students who did not hand in the activities on time, or whose activities were found to be deficient, were warned, and it was ensured that they fulfilled these duties. The instructor and the researcher gave regular feedback regarding the activities of the students. In addition, the students were guided at the points where they had problems regarding the topic or the activities.

In addition to experimental studies, thematic procedures were also employed in order to strengthen the pre/post-complementary data, and to increase the validity and reliability of the study. In this dimension, which was conducted to determine the effectiveness of the FCM, the participants' opinions were sought about the method applied. For this purpose, a semi-structured interview form which was prepared by the researchers and examined by experts, was applied to twenty-seven teacher candidates selected according to the maximum variation sampling within the experimental group, and data were collected. Data were analysed using content analysis by taking into account the action research pattern. Such action research, which combines the research and implementation processes, is defined as an approach that involves collecting and analysing systematic data to identify problems related to an implementation process, or to understand and solve a problem that has already emerged (Yildirim \& Simsek, 2013). In addition, action research is also described as systematic research involving practice, and as a systematic research design for solving problems encountered in learning environments or in everyday life, by finding solutions to the problems and putting them into practice (McKay, 1992). Action research involves several stages (Elliott, 1991). Firstly, the question of the FCM's effectiveness in learning environments was examined. In this regard, the students who participated in the research were asked various questions about the effectiveness of the FCM to collect data. The available data had to be collected within the framework of a plan, and a plan needed to be made. In accordance with the plan, materials and resources that might be needed during the teaching-learning process were provided. After the preparation and completion of the plan, the implementation process was carried out. At the end of this process, the FCM's ability to meet or not meet the relevant expectations might emerge. This part of the research was carried out in line with the stages of action research by providing suggestions based on the data.

In order to ensure the reliability of the research, and to strengthen the defended ideas, direct citations from some student opinions were provided in the text. When these citations were shown, teacher candidates were 
coded as $S_{1}$ (Student 1), $S_{2}$ (Student 2), etc. The data obtained in terms of the reliability of the research were presented as they were, without any interpretation, and the opinions of the field experts were ascertained during the reporting process. In order to ensure the validity of the study, attention was paid to ensuring that the themes and codes were significant and consistent, and were strengthened using different data sources (Miles \& Huberman, 1994). In addition, data analysis was performed to determine the agreement between data encoders. Agreement values were calculated, and the range of values was found to be between .720 and .881 that is, "... at a very good level of agreement".

\section{Complementary Information Stage}

The ultimate aim of the multi-complementary approach was to integrate the data and findings obtained in the first two stages, and to achieve a complementary result. This stage, which was the final stage of the research, involved the combination of pre-complementary and post-complementary stages. At this point, the aim was to clarify all aspects of the issue by combining the pre-complementary information that identified the current situation with the FCM, and the post-complementary information that played a complementary role in the absence of the situation. At this stage, it was possible to obtain complementary information as a result (Batdi, 2017). The idea of examining a subject from a holistic perspective in the current research was based on the need to make an effort for learners to be more conscious, respectful, fair, creative, productive, healthy, socially aware, and enjoying a social and natural life within the context of a holistic education, instead of just raising well-educated individuals by evaluating learners only in one way, such as the leading names such as Montessori, Steiner, Dewey or Ferrer thought many years ago (Miller, 2005). The matter that we want to emphasize here is that the topic researched using a multi-holsitic approach including much more extensive analyses instead of making unidirectional evaluations, will provide the readers, including other researchers in the field, with studies that present creative and productive ideas with a broader perspective. On the other hand, it can be said that complementary information, which is intended to be achieved in the context of the MCA, can be considered as complementary information for the current study. As a matter of fact, Russell (1912) stated that achieving holistic reality is like a stopover on a long journey, and that the point reached is just one step closer to the holistic reality, not the final point, which brings clarity to this situation. Because the developments and changes in the current technological age bring about changes in the fields of science and research at the same rate, the so-called final point is always the stopover point, and we have yet to reach the 'final point' which is by definition unattainable. However, the latest information obtained under the current conditions should be considered as complementary information for that moment in time, and further studies and research should be carried out. In addition, apart from the synthesis process which occurred during the complementary information stage, suggestions are also put forward based on the results obtained. Therefore, this stage is not a simple combination. Rather, it reveals a new and unique feature. In this respect, it is thought that the present study contains both an original and a comprehensive process and will contribute to the educational evaluation of the model.

\section{FINDINGS}

In this part of the study, the findings obtained in the context of the MCA are presented in detail, and interpreted separately. Firstly, meta-analytical and thematic data based on document analysis were given. In the second stage, experimental and thematic findings were included and, in the final stage, commentary on the synthesis stage, in which complementary information was intended to be provided, was included. The statistics showing the education level, type of publication, study year, and the duration of application, sample size and subject area, frequency and percentage values of the meta-analytical examination included in the analysis related to the FCM, are presented in Table 2. 
Table 2. The frequency and percentage values of the studies that include data on the impact of $\mathrm{fcm}$ on academic achievement scores for categorical independent variables

\begin{tabular}{|c|c|c|c|c|c|}
\hline Variable & $\mathbf{f}$ & $\%$ & Variable & $\mathbf{f}$ & $\%$ \\
\hline Teaching Level & & & Year & & \\
\hline Primary School & 4 & 6.3 & $2013 / 2014$ & $5 / 5$ & $7.8 / 7.8$ \\
\hline Secondary School & 10 & 15.6 & $2015 / 2016$ & $9 / 18$ & $14.1 / 28.1$ \\
\hline High School & 13 & 20.3 & $2017 / 2018$ & $13 / 12$ & $20.3 / 18.8$ \\
\hline University & 36 & 56.3 & 2019 & 2 & 3.1 \\
\hline Other & 1 & 1.6 & & & \\
\hline Duration of Application (Weeks) & & & Subject Area & & \\
\hline $2-4$ & 12 & 18.8 & Science & 18 & 25.4 \\
\hline $5-6$ & 13 & 20.3 & Maths & 12 & 16.9 \\
\hline $7-8$ & 13 & 20.3 & Social Sciences & 13 & 18.3 \\
\hline $9-18$ & 21 & 32.8 & Foreign Language & 19 & 26.8 \\
\hline Unspecified & 5 & 7.8 & Computer & 9 & 12.7 \\
\hline Publication Type & & & Sample Size & & \\
\hline Articles & 27 & 21.9 & $\begin{array}{l}\text { Small Sample } \\
\text { (Between 1-49) }\end{array}$ & 20 & 29.9 \\
\hline Master's Thesis & 14 & 42.2 & $\begin{array}{l}\text { Medium Sample (Between } \\
\text { 50-99) }\end{array}$ & 33 & 49.3 \\
\hline Doctoral Thesis & 23 & 35.9 & $\begin{array}{l}\text { Large Sample } \\
\text { (100 And Above) }\end{array}$ & 14 & 20.9 \\
\hline
\end{tabular}

When Table 2 is examined in terms of teaching grades, it can be seen that the highest number of studies were conducted in universities $(56.3 \%)$ and the fewest number of studies were conducted in primary schools $(6.3 \%)$ and secondary schools (15.6\%). It can be said that the small degree of implementation of this model in primary and secondary schools is due to the fact that students may not be able to access technological tools such as computers and the internet in their homes. This may also be the reason why students do not watch the videos that they should watch. Table 2 shows that $42.2 \%$ of the studies took the form of a Master's thesis, $35.9 \%$ doctoral theses, and $21.9 \%$ articles. In terms of the distribution by years, 2016 was the year in which the greatest number of studies were conducted with eighteen $(28.1 \%)$ studies, while the least number of studies were carried out in 2013 (7.8\%) and 2014 (7.8\%). In addition, two publications were published in 2019 and these studies were included in the analysis. In terms of application times, most studies were conducted over a 9-18 week period (32.8\%); and few studies not specifying their application period. Considering the sample size, it was observed that twenty (29.9\%) of the studies were performed with a small sample, thirty-three studies (49.3\%) with a medium sample, and fourteen studies (20.9\%) with a large sample. Finally, it was observed that the highest number of studies was conducted in the field of Foreign Language Education with nineteen (26.8\%) studies, followed by Science Education with eighteen (25.4\%) studies, and the least number of studies were conducted in the field of Computers (12.7\%).

Table 3. The homogeneous distribution value, mean effect size and confidence intervals of the studies included in the meta-analysis according to the effect models related to the academic achievement scores

\begin{tabular}{|c|c|c|c|c|c|c|c|c|c|}
\hline \multirow[b]{2}{*}{ Model Type } & \multirow[b]{2}{*}{$\mathrm{n}$} & \multirow[b]{2}{*}{ Z } & \multirow[b]{2}{*}{$\mathrm{p}$} & \multirow[b]{2}{*}{$\mathrm{Q}$} & \multirow[b]{2}{*}{$\mathrm{df}$} & \multirow[b]{2}{*}{ ES } & \multirow[b]{2}{*}{ SE } & \multicolumn{2}{|c|}{$\% 95$ Confidence Interval } \\
\hline & & & & & & & & Lower Limit & Upper Limit \\
\hline SEM & 71 & 13.165 & 0.000 & 354.326 & 70 & 0.346 & 0.026 & 0.295 & 0.398 \\
\hline REM & 71 & 7.502 & 0.000 & 88.945 & 70 & 0.462 & 0.062 & 0.341 & 0.583 \\
\hline
\end{tabular}


Table 3 shows the distribution values of the studies included in the meta-analysis according to the statistical models. It can be said that the distribution is heterogeneous, seeing that the Q-statistical value (354.326) is greater than the critical value (90.531). Therefore, in the calculations made according to REM, the standard error was calculated as 0.062 , the upper limit of the $95 \%$ confidence interval was 0.583 and the lower limit was 0.341 . The effect size value was calculated as $E S=0.462$. The medium level of this value, according to the Thalheimer and Cook's (2002) classification, suggests that FCM has a positive effect on academic achievement.

Table 4. Effect size of studies on different dimensions according to academic achievement

\begin{tabular}{|c|c|c|c|c|c|c|c|c|c|}
\hline & \multirow{2}{*}{ Variables } & \multirow{2}{*}{$\mathrm{N}$} & \multirow{2}{*}{ ES } & \multicolumn{2}{|c|}{$\% 95$ Confidence Interval } & \multirow{2}{*}{$\mathrm{Q}_{\mathrm{B}}$} & \multirow{2}{*}{ Z } & \multirow{2}{*}{$\mathrm{df}$} & \multirow{2}{*}{$\mathrm{p}$} \\
\hline & & & & Lower Limit & Upper Limit & & & & \\
\hline \multirow{5}{*}{ 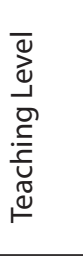 } & Primary School & 5 & 1.137 & 0.489 & 1.784 & 5.133 & 7.677 & 3 & 0.162 \\
\hline & Secondary School & 11 & 0.257 & -0.166 & 0.680 & & & & \\
\hline & High School & 13 & 0.450 & 0.134 & 0.766 & & & & \\
\hline & University & 42 & 0.443 & 0.311 & 0.576 & & & & \\
\hline & Sum & 71 & 0.452 & 0.337 & 0.568 & & & & \\
\hline \multirow{6}{*}{ 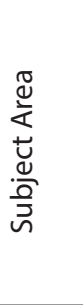 } & Science & 18 & 0.463 & 0.237 & 0.689 & 0.408 & 8.103 & 4 & 0.982 \\
\hline & Social Sciences & 13 & 0.513 & 0.178 & 0.848 & & & & \\
\hline & Foreign Language & 19 & 0.446 & 0.211 & 0.682 & & & & \\
\hline & Computer & 9 & 0.509 & 0.299 & 0.720 & & & & \\
\hline & Maths & 12 & 0.395 & 0.035 & 0.754 & & & & \\
\hline & Sum & 71 & 0.472 & 0.358 & 0.586 & & & & \\
\hline \multirow{6}{*}{ 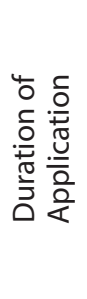 } & $2-4$ & 13 & 0.744 & 0.389 & 1.100 & 6.960 & 7.333 & 4 & 0.138 \\
\hline & $5-6$ & 16 & 0.243 & -0.014 & 0.501 & & & & \\
\hline & $7-8$ & 13 & 0.384 & 0.066 & 0.702 & & & & \\
\hline & $9-18$ & 24 & 0.525 & 0.335 & 0.716 & & & & \\
\hline & Unspecified & 5 & 0.307 & 0.055 & 0.560 & & & & \\
\hline & Sum & 71 & 0.429 & 0.314 & 0.544 & & & & \\
\hline
\end{tabular}

Table 4 presents the effect size of the studies on academic success included in the meta-analysis, obtained in terms of teaching grades, subject area and duration of application. According to this, when the homogeneity test was examined in terms of the teaching grade, $\mathrm{Q}_{B}$ was found to be $=5.133$ from a $\mathrm{X} 2$ table, at $95 \%$ significance level, and with 3 degrees of freedom, the $X^{2}$ value was found to be 7.815 . Since the $Q_{B}$ statistic value $\left(Q_{B}=5.133\right)$ is smaller than the critical value of $X^{2}\left(X^{2}(0.95)=7.815\right.$ distribution with 3 degrees of freedom, it can be said that the distribution is homogeneous. Accordingly, it was understood that the overall effect size of the teaching grades $(\mathrm{ES}=0.452)$ was medium according to Thalheimer and Cook (2002). In the light of these findings, it can be said that the application of the FCM affects academic achievement positively, but since there is no significant difference ( $\mathrm{p}=0.162)$, it can be said that academic success has not changed according to the teaching grades. In other words, the fact that no meaningful difference is seen between the grades when the studies of the FCM are evaluated within the context of teaching grades, can be interpreted as the academic success does not change according to the teaching grades.

When the homogeneity test was examined in terms of subject areas, the $\mathrm{Q}_{\mathrm{B}}$ value was found to be 0.41 . The $\mathrm{X}^{2}$ value was calculated as 9.488 with 4 degrees of freedom at the $95 \%$ significance level from the $\mathrm{X}^{2}$ table. Since the $\mathrm{Q}_{B}$ statistical value is smaller than $\left(\mathrm{Q}_{B}=0.41\right) \mathrm{X}^{2}$, it can be said that the distribution between the effect sizes is homogeneous. Accordingly, the overall effect size was found to be $E S=0.472$, and this value was medium according to Thalheimer and Cook (2002). In addition, it can be stated that the distribution of effect sizes is homogeneous, and that the impact of the FCM on academic achievement does not change according to subject area $(\mathrm{p}=0.982)$. 
When the study was examined in terms of duration of application, $\mathrm{Q}_{\mathrm{B}}$ was found to be 6.960. The $\mathrm{X}^{2}$ value was calculated as 9.488 with 4 degrees of freedom at the $95 \%$ significance level from the $\mathrm{X}^{2}$ table. Therefore, it is understood that the $\mathrm{Q}_{B}$ statistic value is less than $\mathrm{X}^{2}$. In this case, it can be stated that the distribution of effect sizes is homogeneous, and that the effect of the FCM on academic achievement does not change in terms of the duration of application $(\mathrm{p}=0.138)$. In this case, it can be said that the level of academic achievement is independent of the duration of application in the courses in which the FCM was used. On the other hand, the overall effect size value is $E S=0.429$, and this is at a medium level. This finding may be interpreted as the use of the FCM affecting academic achievement positively at a medium level.

\section{The Effectiveness of the FCM within the Scope of the Document Analysis-Based Thematic Review}

The themes and codes of the thematic study carried out to complete the data in stages 1a, 1b, 1c, 1d, 1e and $1 \mathrm{f} \mathrm{obtained} \mathrm{as} \mathrm{a} \mathrm{result} \mathrm{of} \mathrm{the} \mathrm{document} \mathrm{analysis,} \mathrm{are} \mathrm{presented} \mathrm{in} \mathrm{different} \mathrm{forms} \mathrm{and} \mathrm{models.} \mathrm{As} \mathrm{a} \mathrm{result} \mathrm{of}$ the detailed examination, thematic data were grouped under different themes in three models. The effects of the FCM on the personal dimension (Figure 5), the effect on the learning process (Figure 6), the effect on the sensory dimension (Figure 7), the positive aspects of the FCM (Figure 8), the negative aspects of the FCM and suggestions (Figure 9) are presented below.

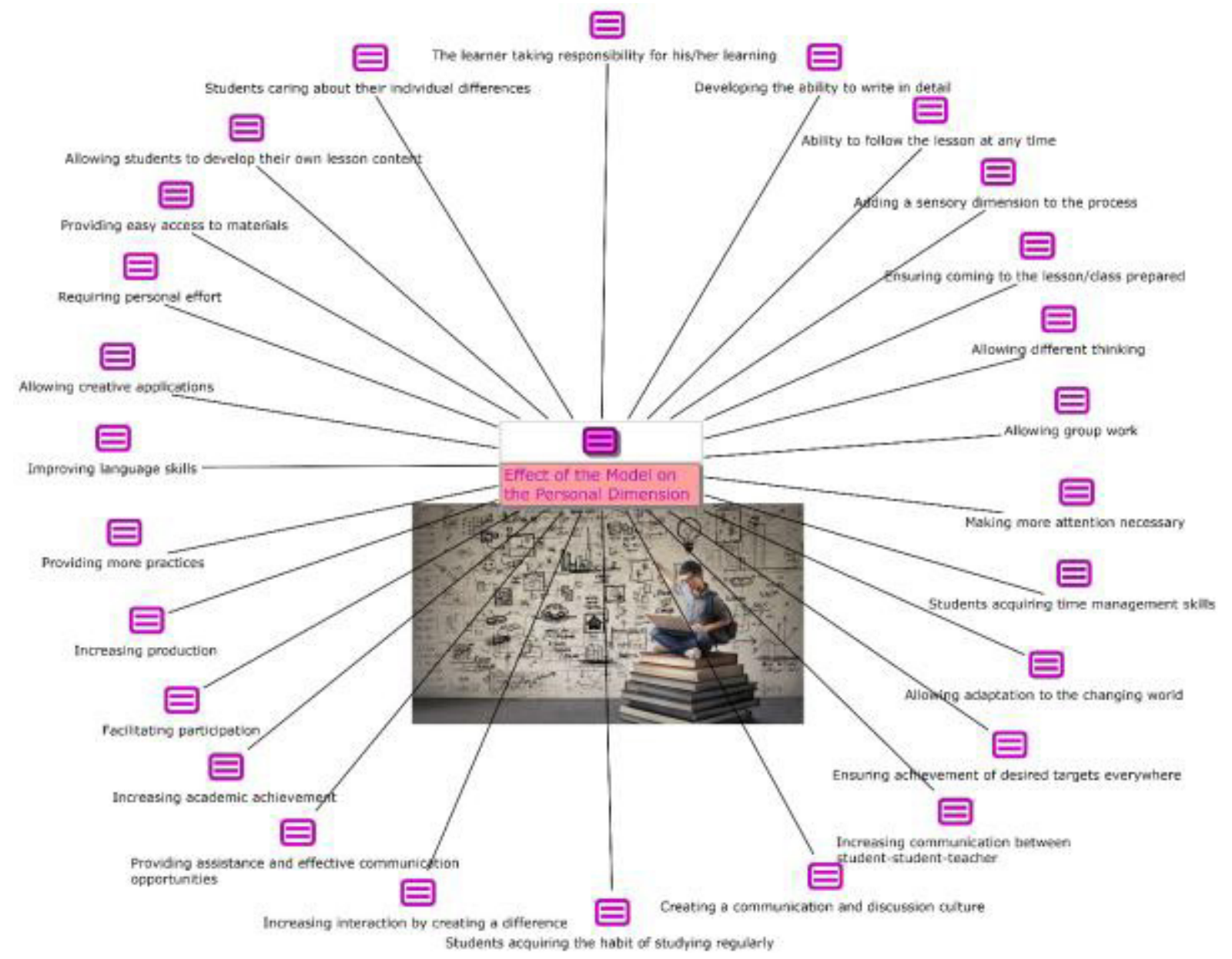

Figure 5. Effect of the model on the personal dimension

In Figure 5, some of the codes expressed in the context of the impact of the FCM on the personal dimension can be expressed as: following the course at any time, allowing creative applications, the learner taking responsibility for his/her own learning, gaining a regular studying habit, requiring personal effort, caring 
about the individual differences of the students, providing time management skills, and allowing adaptation to the changing world. In the context of this theme, - expressions such as "Doing activities in class allows me to give more importance and pay more attention. Because when I am at home, maybe I can't take it seriously.", which was cited from the419422-.93 coded study; "Creative activities, such as the games we play on the internet, have enabled us to use language in different ways", which was cited from the 445646-s.60 coded study and "I think it increases our ability to communicate with our friends and teachers" which was cited from the 429617-p.70 coded study. These were considered as reference sentences and were used in the creation of codes.

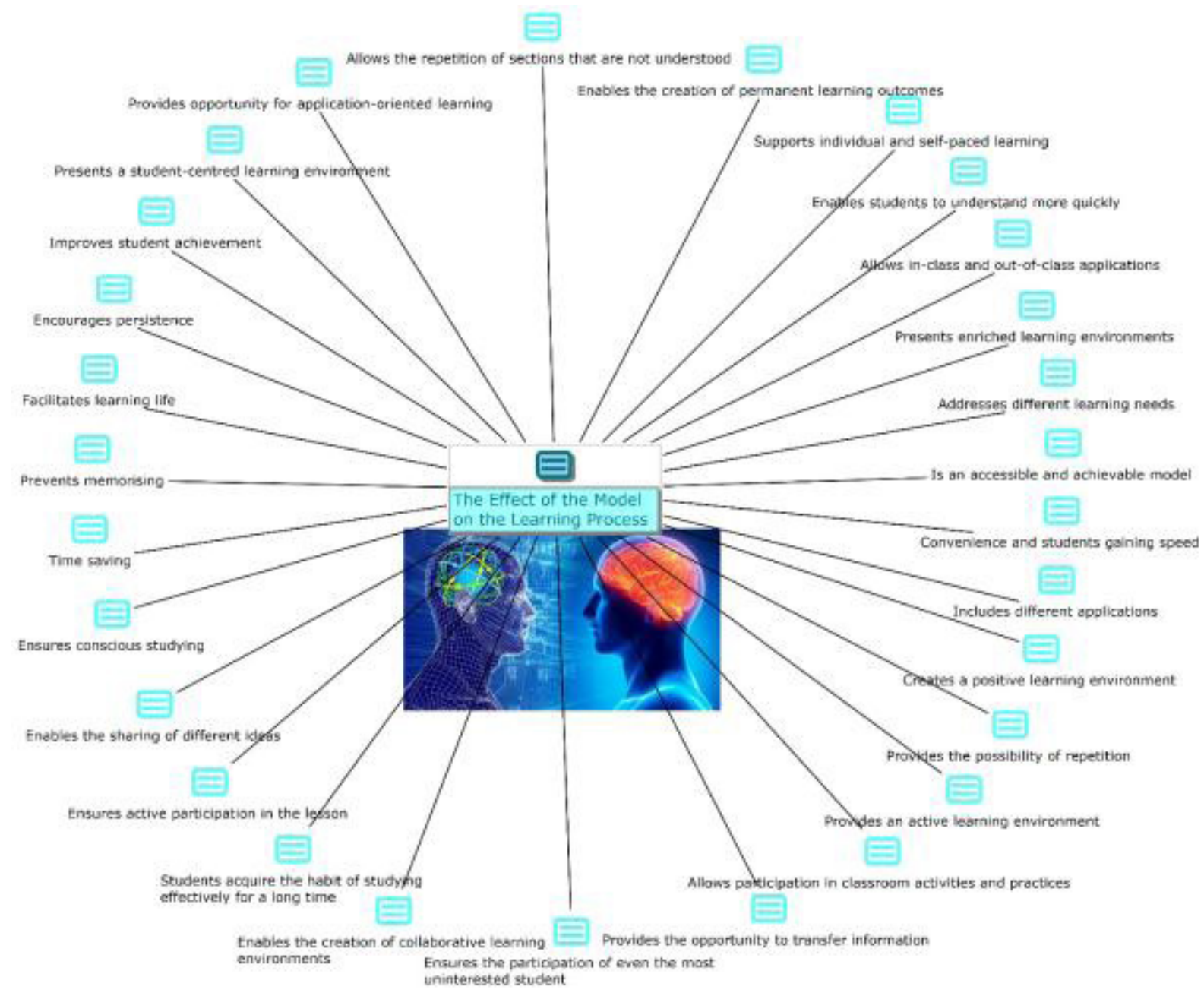

Figure 6. Effect of the model on the learning process

When Figure 6 is examined, it can be seen that codes related to the effect of theFCM on the learning process have been created. Some of the codes generated for this model are specified as "...supporting individual and self-paced learning, allowing in-class and out-of-class applications, presenting enriched learning environments, preventing memorising, providing the possibility of repetition, providing the opportunity to transfer information, creating a positive and active learning environment, ensuring the formation of collaborative learning environments, presenting a student-centred learning environment, providing opportunities for application-oriented learning". Some expressions that are referenced in the creation of related codes can be specified as expressions that are cited from the 429617-66 coded study: "Some friends have a little more capacity than others, while some understand it at once, while others understand it after three times. Everyone can watch and repeat the video according to himselfiherself. Everyone learns at their own pace" or the expressions cited from the 383901-71 coded study: "Now, our routine of having a lesson in the classroom and doing homework at home that we repeated regularly every day ended. We are able to follow the lessons at the time and space we determine, and we can do homework and carry out much richer activities in the classroom" and also 
the expressions cited in the 429617-69 coded study: "In other classes, reading and writing exercises are performed, there is not much activity. But in this class, we do activities and practices. We practise on the computer. This makes it more enjoyable and lasting".

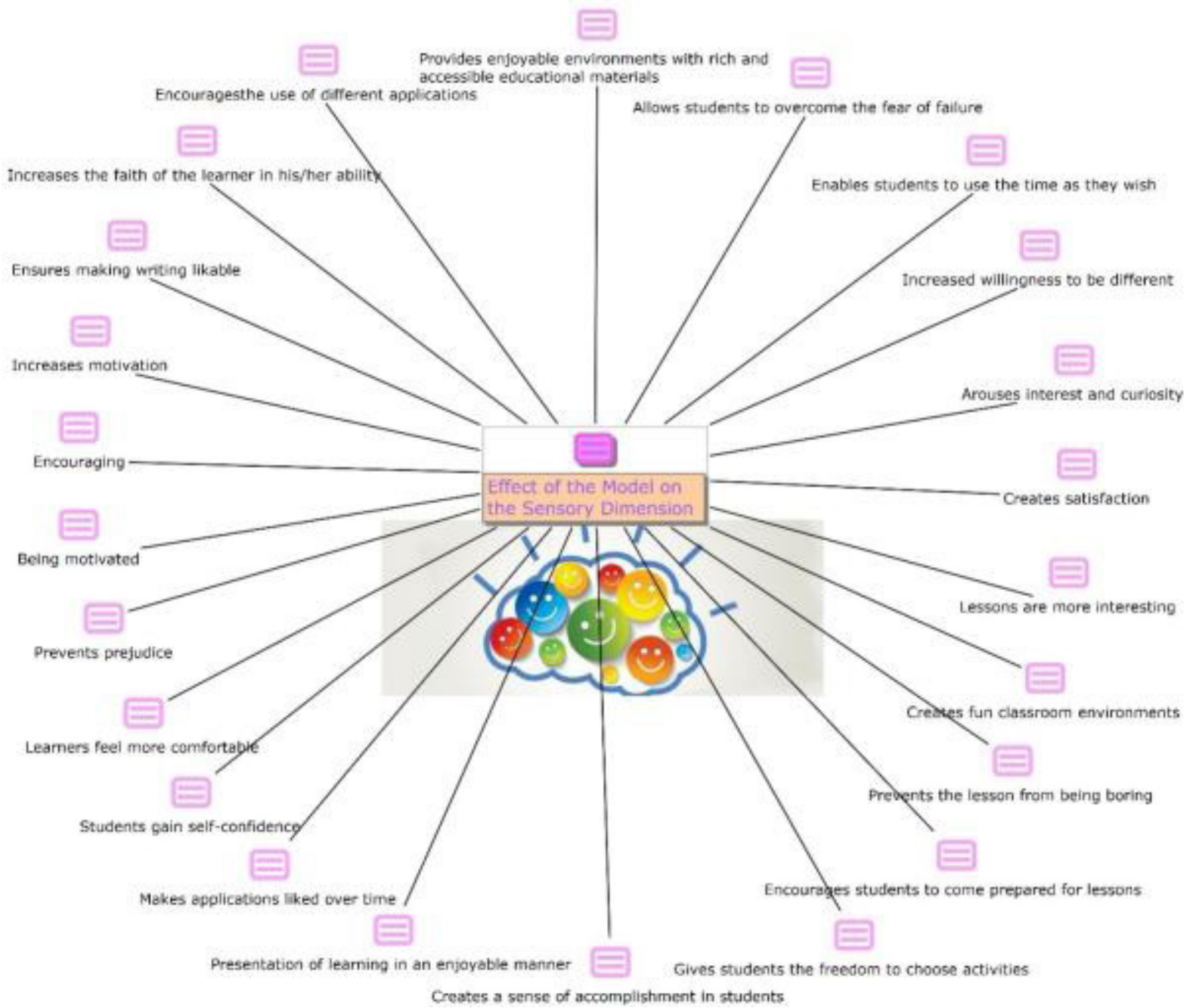

Figure 7. Effect of the Model on the Sensory Dimension

Figure 7 shows the codes expressed in relation to the effect of the FCM on the sensory dimension. Some of these are "...being motivated, encouraged, preventing the lesson from being boring, creating satisfaction, students gaining self-confidence, creating fun classroom environments, increasing the faith of the learner in his/her ability, creating a sense of accomplishment in students and allowing them to overcome the fear of failure". Expressions that were cited from the 383901-72 coded study and which may be referenced to these codes are: "Thanks to the model, my learning life became easier, and many of my prejudices were broken down. It makes the lesson more fun. I like the videos our teacher has prepared. In fact, I watched them several times. We got rid of the boredom of the textbook" or the expression cited from the 394794-79 coded study: "Having different activities, group work, applications increased my motivation". 


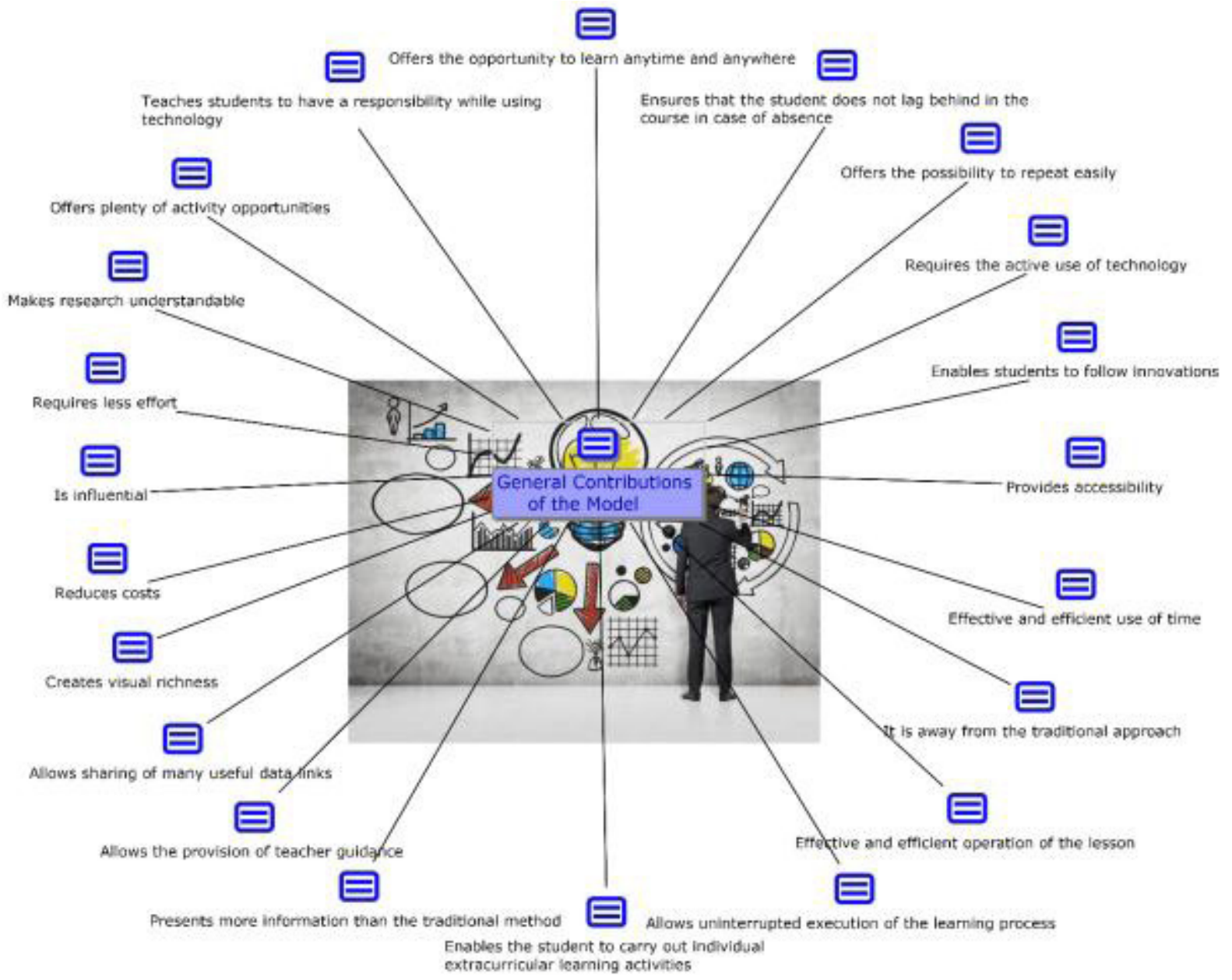

Figure 8. General contributions of the model

Some of the general contributions of FCM can be expressed as: "...effective and efficient use of time, offering the possibility to repeat easily, offering the opportunity to learn anytime and anywhere, requiring active use of technology, offering plenty of activity opportunities, allowing uninterrupted execution of the learning process, providing accessibility, ensuring that the student does not lag behind in the course in case of absence". Related codes were created based on expressions such as: "We took lessons like this, but they were temporary. I'm pleased with this because it is done in a different way. Even though I was prejudiced at first, it offers more than what the teacher teaches in class. When you hesitate about something, you can access all the visual materials, presentations, audio recordings, videos etc. at any time you want. These have provided permanence" (419422-91); "It is advantageous in terms of time. You can progress fast in class. Student-teacher interaction is also high. And visual materials, I think. Normally when presentations are used to teach the lesson in the classroom, it does not attract much attention, but when it comes to using video and sound, it is much better" (419422-.94); "The interaction between the home and school enhances our learning. Because we spend our free time learning at home and, at school, we have the opportunity to repeat and practise again. I think this is a very important factor" (429617-76).

In addition to the positive aspects of the FCM, it is understood that it has some limitations, and these limitations and suggestions for solutions to them are given in Figure 9. 


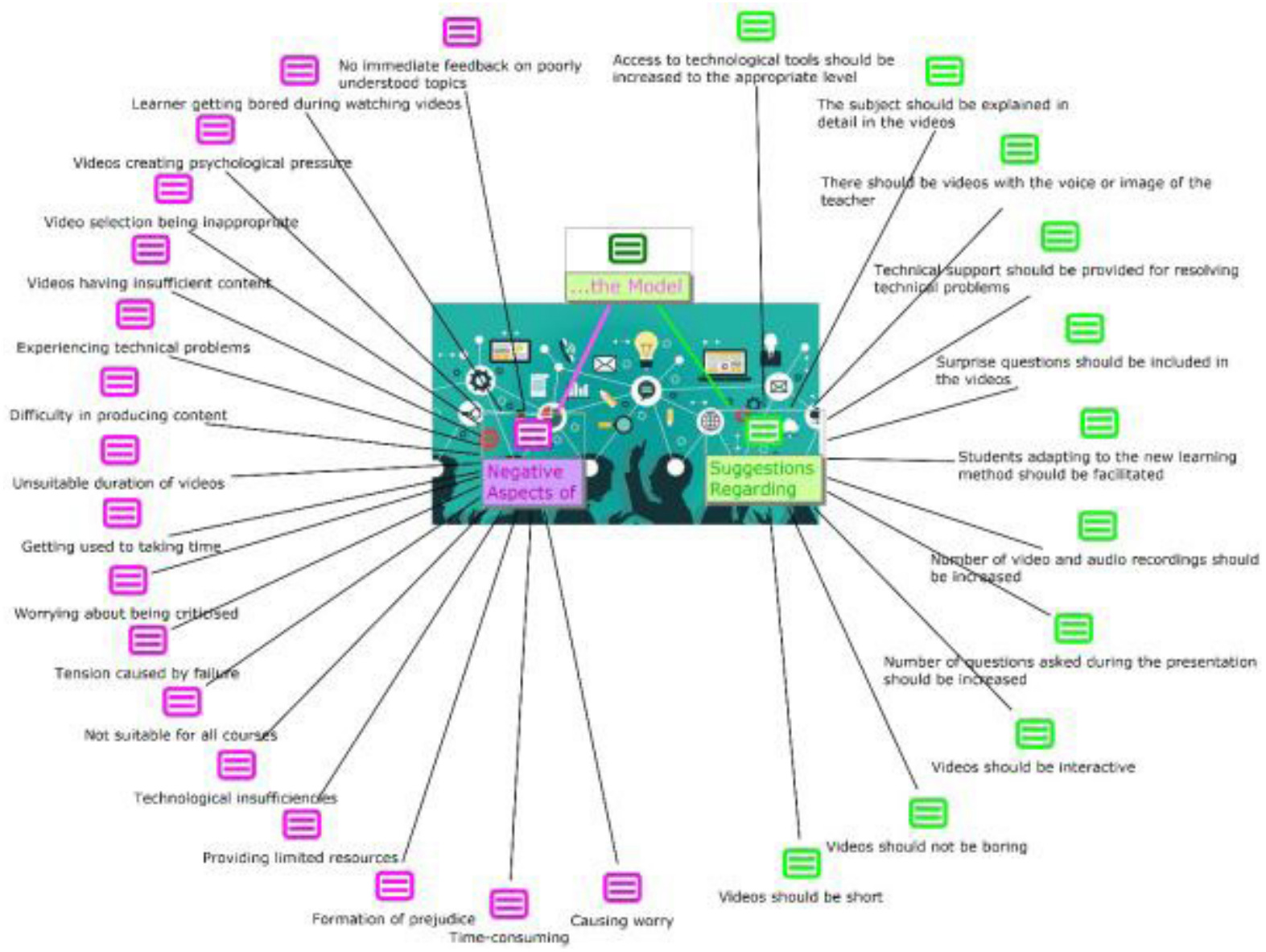

Figure 9. Negative aspects of the model and suggestions

Figure 9 shows the problems encountered in the implementation of the FCM. Some of the most prominent of these codes are "...duration and contents of video being not suitable, no immediate feedback on poorly understood topics, technological insufficiencies, difficulty in producing content, getting used to taking time, providing limited resources, experiencing technical problems and not suitable for all courses". Related codes are based on expressions such as: "If we don't understand something when we watch a video, we can't ask, but we can ask the teacher at school" (372445-83); "Technical problems may occur in the model. I've had technical problems once. The computer malfunctioned in the lab. ..." (429768-62); "Sometimes, the anxiety of forgetting to watch the video caused me to be tense because of the responsibility I felt. There is no such obligation in traditional education, the teacher will explain the topic anyway when you go to school, so you feel relaxed before the class"(429768-61). However, when the studies were examined in detail, it was seen that some suggestions had been presented regarding the problems mentioned. Some of these suggestions, which could eliminate or reduce the relevant problems, could be expressed as "videos should be short and not boring, access to technological tools should be increased to the appropriate level, technical support should be provided for resolving technical problems, students adaptation to the new learning method should be facilitated". During the creation of the relevant codes, statements cited from the 394794-s.80 and the 424655-p.47 coded studies were taken as references: "In the videos, the subject should be explained in more detail and attention should be paid not to bore the student". "The questions asked during the presentation can be increased and, in the presentation, it can be advanced by giving the correct answers to the questions. Also, motivation can be increased by giving a mark at the end of the presentation". These findings show that, despite the limitations that may occur during the use of the FCM in the learning process, it can be used effectively as a learning approach if suitable measures are taken. 


\section{Comparison of Pre-test and Post-test Achievement Score Results of Groups after the Experimental Study}

In order to determine whether or not there was a significant difference between the pre-test and post-test academic achievement scores of the students in the study group, independent groups t-test was used. The results are shown in Table 5.

Table 5. Comparison of pretest and posttest achievement score results of experiment and control group

\begin{tabular}{|c|c|c|c|c|c|c|c|c|c|}
\hline \multirow{2}{*}{$\begin{array}{l}\text { Achievement } \\
\text { Test }\end{array}$} & \multirow{2}{*}{ Groups } & \multirow{2}{*}{$\mathrm{n}$} & & \multirow[b]{2}{*}{ ss } & \multirow{2}{*}{ sd } & \multicolumn{2}{|c|}{ Levene } & \multirow[b]{2}{*}{$\mathrm{t}$} & \multirow[b]{2}{*}{$\mathrm{p}$} \\
\hline & & & & & & $\mathrm{F}$ & $\mathrm{p}$ & & \\
\hline \multirow[b]{2}{*}{ pretest } & Experiment & 34 & 4.18 & 2.57 & \multirow[b]{2}{*}{62} & \multirow[b]{2}{*}{0.500} & \multirow[b]{2}{*}{0.482} & \multirow[b]{2}{*}{-0.802} & \multirow[b]{2}{*}{0.426} \\
\hline & Control & 30 & 4.66 & 2.27 & & & & & \\
\hline \multirow[b]{2}{*}{ posttest } & Experiment & 34 & 11.68 & 2.40 & \multirow[b]{2}{*}{62} & \multirow[b]{2}{*}{1.782} & \multirow[b]{2}{*}{0.187} & \multirow[b]{2}{*}{2.095} & \multirow[b]{2}{*}{0.04} \\
\hline & Control & 30 & 10.27 & 2.97 & & & & & \\
\hline
\end{tabular}

When Table 5 is examined, it can be seen that the pre-test achievement scores of the experiment and control groups are close to each other, and no statistically significant difference is observed ( $t=-0.802 ; \mathrm{p}>.05)$. In other words, it can be said that the groups were equal prior to the experimental procedure. On the other hand, there were significant differences between the post-test achievement scores of the experimental and control groups $(t=2.095 ; \mathrm{p}<.05)$. It is understood that the difference was in favour of the experimental group with a rate of 1.41 . Therefore, this finding can be interpreted as claiming that the transformed classroom model positively affects the students' academic success in the Information Technology course.

\section{Thematic Findings Obtained from the Opinions of the Participants after the Experimental Study}

In this section, the interpretation of the thematic findings obtained from the interviews with the students participating in the FCM is included. With the evaluation of the opinions received, it was observed that two models entitled the positive and negative aspects of the FCM emerged.

Figure 10 shows the themes and codes related to the positive aspects of the FCM. Some of the most prominent codes can be expressed as "time saving, offering more applications, encouraging students to come to class prepared for the lesson, providing educational guidance at any time, ensuring full class participation, allowing students to learn anywhere, allowing repetitions at any time, providing cooperative learning, ensuring that no homework is given" $S_{8}$ coded participant, which is one of the sources from which the relevant codes are quoted, stated as follows: "We come from home having learned lessons, and we learn parts that we don't know at school by doing more practice. We learn parts we do not understand by practising" and $S_{1}$ coded participant stated "It is more effective for us in terms of saving time, and because we can learn in collaboration with our classmates as a team". Finally, $\mathrm{S}_{23}$ emphasises individual responsibility "The student understands the lesson better. The student learns something by taking responsibility for his/her learning". 


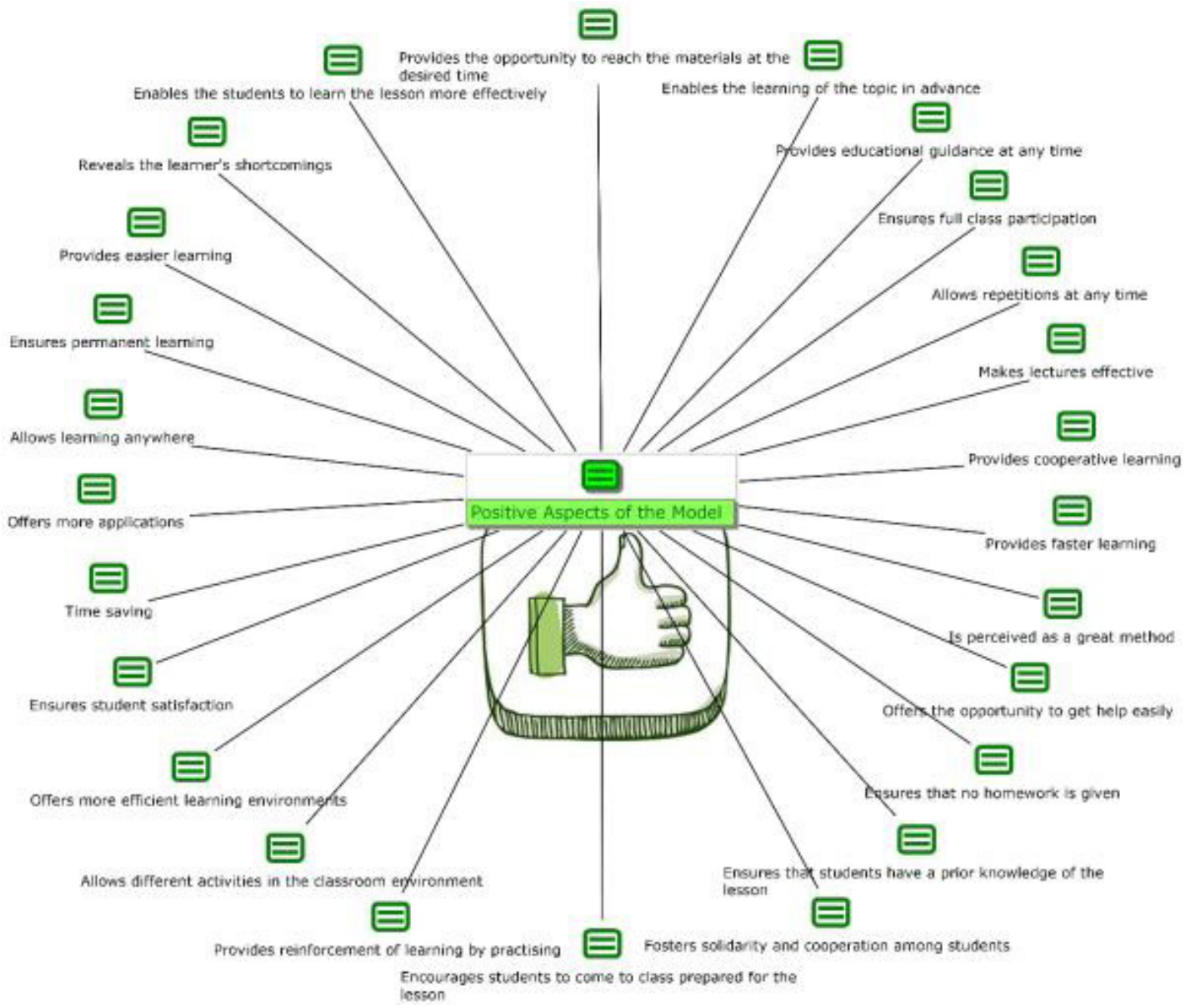

Figure 10. Model for the positive aspects of FCM

Figure 11 shows that different codes are formed as a result of evaluating the opinions expressed by the participants about the negative aspects of the FCM. In this context, it can be stated that some of the negative aspects of the model are coded as "lack of materials required, it is not a substitute for the teacher's role, problems during the implementation stage, unclear parts cannot be learned, videos being not informative enough, changing existing habits being difficult, lack of one-to-one attention with learners, unsuitable for crowded classes". Some of the sources from whom codes related to this model are cited include $\left(S_{3}\right)$ : "It's causing trouble for those who don't have a computer or the internet... and it can affect them negatively"; $\left(S_{5}\right)$ : "As I learned the lesson at home, for the first time I heard some terms and concepts, and I found them difficult to understand. Since there was no one, it was hard to find the answers. But if we learned the lesson in the school, we would ask the teacher about what we didn't understand"; $\left(S_{13}\right)$ : "The video was not very effective. Some videos were too short. I also had problems with sound sometimes". 


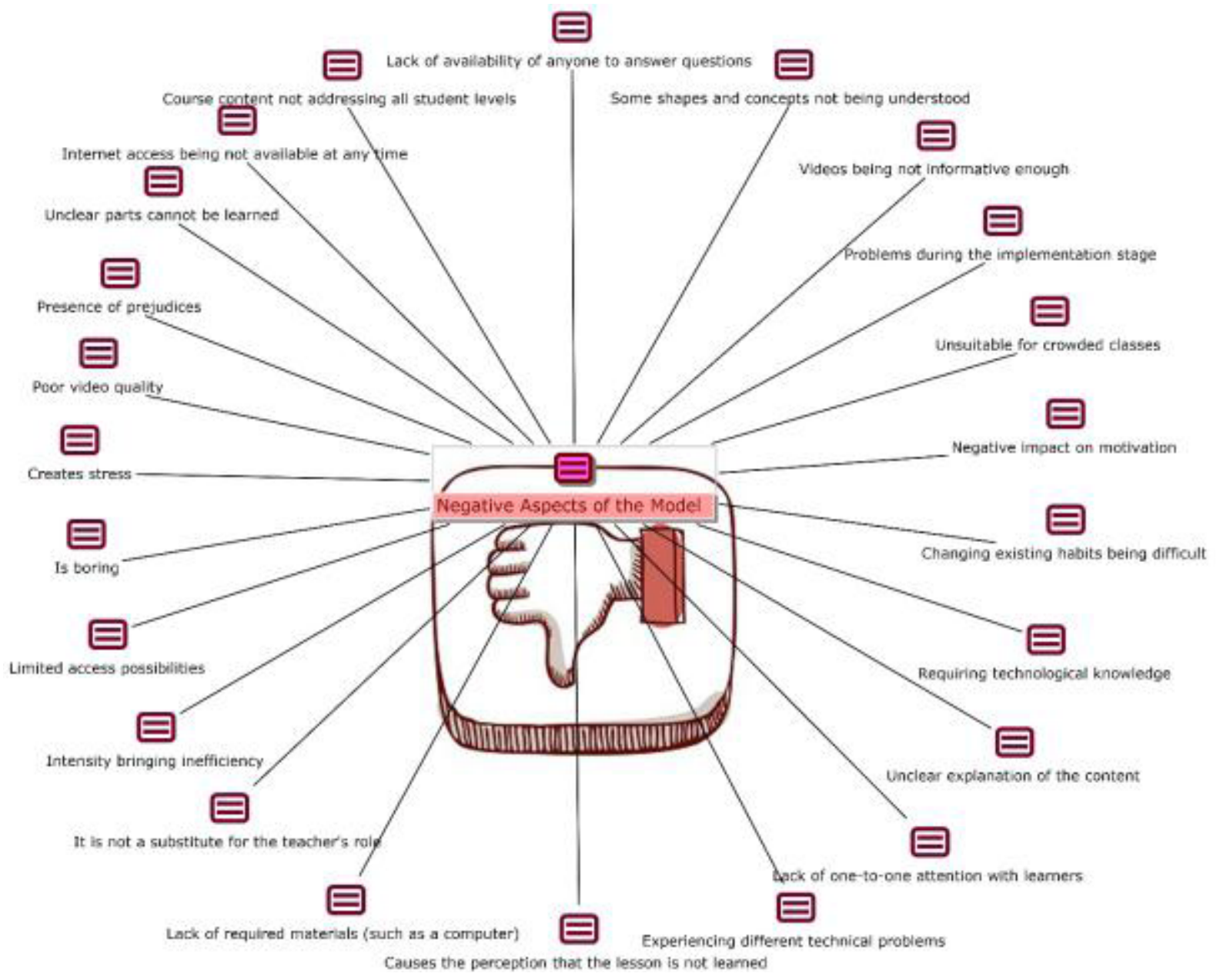

Figure 11. Model regarding the negative aspects of FCM

\section{DISCUSSIONS AND CONCLUSION}

This was a comprehensive study conducted to determine the effect of the FCM on academic achievement in order to evaluate the scope of the FCM in the literature in the context of the current research, and to determine how effective the model is in terms of different variables. Operations were performed in line with MCA. First of all, a meta-analytical examination was applied to reveal the current state of the FCM approach in the scientific literature in terms of related research that had been conducted. In this context, in order to determine the impact of the FCM approach on students' academic achievement scores, the studies included in the meta-analysis were analysed. Most studies were conducted at university level (56.3\%); frequently in the form of Master's publications (42.2\%); in 2016 (28.1\%); in a 9-18 weeks application process (32.8\%); in 50-99 sample size (49.3\%) and in foreign language teaching $(26.8 \%)$. In the present case, that more studies are performed on the FCM especially at the university level, may be given as the justification for the predominant preference of this method, which foregrounds self-study and ensures the realization of the learning process of the student out of the classroom through online presentations (teachers' sound recordings or online activities that $\mathrm{s} / \mathrm{he}$ has prepared). Besides, it may also be commented that it is preferred more in the student groups at this level and in this age group (university level) because it includes the practice of in-class student-centered activities, giving more time in the classroom to aid the understanding of hard concepts, answering students' questions, providing the involvement of students in active learning, and establishing a connection with everyday life and therefore inculcates the habit of self-learning (Stone, 2012). On the other hand, as a result of the meta-analysis of studies which included academic achievement scores, it was found that the FCM had a positive medium impact on academic achievement (ES=0.462). This result shows that the FCM has a positive effect on academic achievement. In a doctoral study conducted on this subject, it concluded that the FCM has positive effects in terms of academic success (Wiginton, 2013) and supports 
the current research. Besides, in a study where FCM was used in nursing education (Presti, 2016), in a study where 107 pieces of research were accessed through a literature search, it was concluded that the FCM has positive effects. The results obtained both support the result of the present research and indicate that the positive effect of the FCM shows similarity in different areas and in different bodies of literature.

Within the scope of the pre-complementary stage of the research, in addition to meta-analysis, meta-thematic analysis was also carried out, and various themes and codes were created from the results of the studies accessed. At this point, the personal impact of the FCM were found to be improved time management, increasesd individual responsibility, increased preparedness, improved creative skills, communication, language skills, solidarity and cooperation, the enhancement of planned and regular study, easy access to material, adaptation to change and development, improved production and a contribution to academic achievement. Therefore, it is understood that the FCM has a positive effect on the development of different skills on the part of the learner as well as ensuring that the learner achieves a certain level in terms of personal development. It was found that the FCM has similar results in different studies in the related literature. It was found that students accept their own learning responsibilities with the FCM, attend to the lesson more, and participate effectively in the activities/practices during the lesson (Akgun, 2015; Bergmann \& Sams, 2012; Staker \& Horn, 2012; Tucker, 2012). In addition, in this model, when differences arising from the differing learning speeds of the students are taken into account, it has been determined by different studies conducted on the FCM that equal opportunities are offered in education, and interactive and cooperative learning environments are created (Chen et al., 2014; Chu \& Sun, 2015; Halili \& Zainuddin, 2015; Rutkowski \& Moscinska, 2013; Yavuz, 2016). In addition, it has been found in some studies that the model allows the creation of permanent learning outcomes by enabling the use of rich and accessible materials (Aydin, 2016; Mason et al., 2013; Turan, 2015). The similar and overlapping results of these studies support and strengthen the current study. Additionally, the effects of the FCM on the learning process have been shown to be positive in terms of individual speed, permanent learning, preventing memorising, knowledge transfer, cooperative learning, different applications, positive learning environments and applied learning. Looking at the literature, similar findings have been found. In these similar findings, it has been stated that the model prevents learning being monotonous by making learning effective and permanent, making it student-centred and making the learning environment richer (Balikci, 2015; Mason et al., 2013; Sirakaya, 2015; Turan, 2015; Yavuz, 2016). In these studies, it was also stated that, thanks to the model, time was used effectively and efficiently, and that it allowed students to repeat the lesson as much as they wished (Bergmann \& Sams, 2012; Fraga \& Harmon, 2014; Johnson, 2012; Roehl et al., 2013; Tucker, 2012).

Regarding the effect of the FCM on the sensory dimension, it was seen that the model was motivating and encouraging, and that the students achieved a sense of success, a belief in being able to do what was required, and an ability to overcome the fear of failure. They were satisfied with the results and gained selfconfidence. At this point, it was concluded in the studies on related subjects that the model saves students from monotony and makes them feel more comfortable by making the classroom process more efficient and fun (Aydin, 2016; Fulton, 2012; Pinto \& Little, 2014; Touchton, 2015). In addition, it was found that students were satisfied with the method applied in terms of the FCM, liked the lesson and found it motivating (Davies et al., 2013; Gilboy et al., 2015; Kara, 2016; Morgan et al., 2015; Pinto \& Little, 2014; Touchton, 2015), which are consistent and supportive results. This may indicate that the learning outcome may therefore be permanent, since it can be interpreted that the FCM ensures learning by making it enjoyable and therefore making the students willing to participate. Besides, in a study conducted on the FCM in the body of the literature (Aydin \& Demirer, 2017), the content analysis and examination of the studies at this point in the body of literature were made. It was also understood at the end of this study that the FCM affected the attitude of the student positively, and it had positive effects on issues such as motivation and student satisfaction.

When the codes mentioned with regard to the FCM's general contributions are evaluated, it is understood that the approach gives freedom in terms of time and space, offers repetition according to learning speed and form (flexible learning), provides visually rich materials, and follows an innovative and modern approach removed from traditionalism. All these codes point to the ease of learning with the FCM and the opportunities it offers in terms of learning. Another contribution of the model is that students who indicate that they do not want to waste time going to lectures, use in-class time more effectively and efficiently, and find more 
opportunity to practise. Moreover, the fact that students could receive help from each other and access their teachers at any time and easily, both during the class and outside the classroom, has caused them to express a positive opinion of the model. At this point, the teacher acts as a guide and mentor whom they can consult. In this respect, the student has become both more active and central in the learning process, with the teacher taking the role of guide. The results of some studies show that the FCM establishes cognitive bridges between the classroom process and the extracurricular process, and ensures uninterrupted execution of the learning process. They also indicate that the students work in collaboration with their peers under the guidance of their teachers (Aydin, 2016; Sirakaya, 2015; Talan, 2018; Yavuz, 2016). In addition, studies have been encountered stating that the model allows students to learn at their own pace at any time and in any place, thus contributing to flexible learning (Bergmann \& Sams, 2012; Mok, 2014), and that it saves on cost, labour and time, provides more opportunity to practise, and encourages students not to lag behind in their school work (Bergmann \& Sams, 2012; Kara, 2016; Qader, 2017). As it can also be understood from these results, the student's practice of the content of the lesson the teacher gives as they comprehend it, and his/ her use of it in problem solving stages, should be seen as important by the students rather than the content of the course that the teacher teaches. As is indicated in the related study results, thanks to the presented online contents and videos within the scope of the FCM, both time and space limitations are eliminated and economic opportunities can be presented. Besides, it can be ensured that the lessons missed or not completely understood can be watched again and again within the scope of the FCM, reinforced through following and understanding. Consequently, it can be stated that these results support our current research results.

In addition to these positive aspects mentioned with regard to the FCM, it has been determined that there are some negative aspects and limitations. In particular, different problems such as technical problems during the use of the application, access to technological tools such as a computer and the internet, and inappropriate video duration and content, have come to the fore. In line with the findings of this study, some other studies have also mentioned similar negative situations with regard to the model. In the relevant literature, among the negative aspects of the FCM, the lack of technical tools, technical problems experienced during the application, and a failure to watch videos before the lesson were seen as necessary to highlight (Boyraz, 2014; Fraga \& Harmon, 2014; Strayer, 2012; Turan, 2015). In order to implement the FCM effectively, such negative aspects have to be eliminated. In this respect, it is of the utmost importance that the students have access to technological tools at the appropriate level, and that they are provided with technical support. However, when videos are prepared in an understandable manner of an appropriate length, and when students' learning processes are facilitated, it can be seen that such problems can be eliminated and that the system can be accepted by students (Kara, 2016; Milman, 2012; Talan, 2018; Yavuz, 2016). Furthermore, video content being prepared in accordance with the relevant topic and being more interesting and striking can make the video both more effective and more fun. In addition, it may be suggested that the duration of the course which students have to follow out of class on a daily basis is arranged so as not to be too onerous and bore the student. Since the student will follow the prepared content willingly and fondly as a result, developments in the desired course are more likely to occur at the end of the process.

In the second stage of the study, it was found that there was a significant difference between the experimental and control groups in terms of the post-test scores in favour of the experimental group with regard to the effect of the FCM on the academic achievement scores in an Information Technology (IT) course. In other words, it can be said that the FCM is more effective in achieving the learning outcomes in an IT lesson compared to traditional teaching methods.

That the FCM, which focuses on student-centered active learning in the classroom and enables the following of the content online out of the classroom has a positive effect, was proved by different researchers in line with the present experimental results. Hibbard, Sung and Wells (2016) in applying the FCM in chemistry teaching at a college, found that the experimental group of students who realized learning using this learning platform showed better performance than the group taught using traditional methods. Besides, they determined that the students' perceptions regarding the use of the FCM were mostly positive, and that this positive situation increased success by ensuring motivation regarding learning. 
At the end of the study, the participants' opinions regarding the FCM were also ascertained. When the findings related to these views were evaluated, it was seen that data similar to the codes identified in the meta-thematic dimension had been obtained. The contributions of the FCM, such as the collaborative environment it provides for learning, repetition, helping each other, participation in the lesson and the opportunity to learn everywhere and anytime, and its negative aspects such as videos being insufficient and not suitable, the requirement for internet access and the lack of instant feedback, means that the results provided by the pre-complementary and post-complementary information overlap completely with each other. Similarly, Nederveld and Berge (2015) attained a result that flipped learning creates a student-centered classroom where they can learn at their own pace while their academic learning levels and paces diverse. Therefore, it can be stated that the results obtained in the first and second stage dimensions of the study overlap. The fact that pre-complementary and post-complementary information achieves similar results in terms of the positive effects of the FCM on success, shows that both dimensions are consistent and support each other. When the literature related to the FCM is examined, there are studies indicating that the model increases success in many areas such as the social sciences, science, medicine, engineering and mathematics (AlJaser, 2017; Atwa et al., 2016; Cakir, 2017; Elian \& Hamaidi, 2018; Foldnes, 2016; Hew \& Kwan, 2018; Saglam, 2016; Thai et al., 2017; Turan, 2015), and some other studies indicate that there is no significant increase in success (Dixon, 2017; Duffy, 2016; Overmyer, 2014; Touchton, 2015; Voltz, 2016). In this sense, the consistency, coherence and similarity of the results of the studies both among themselves and with the related literature, is noteworthy.

The complementary dimension of the research includes pre-complementary and post-complementary results within the scope of the research supporting each other. In this context, the ES value for the FCM being at 0.462 level as a result of meta-analysis in the pre-complementary information, the value of ES being positive in terms of sub-dimensions such as level, subject areas and application times, and the determination of the impact of the FCM's personal dimension with titles such as learning process, sensory dimension, general contributions, positive/negative aspects and suggestions in meta-thematic examinations, explains the summary of the first stage of the research and their complementing each other. On the other hand, the complementary results of the research have been achieved with the creation of positive and negative codes for the model in line with the participatory views from a thematic point of view, and with the findings that there was a significant difference in favour of the experimental group's post-test achievement scores after the FCM application. These results are in the same direction as the results in the first stage means that the pieces are brought together to complete a whole picture with regard to the research. The pre-complementary findings of the present research show that the FCM affects academic success positively in the meta-analysis dimension, and that with the meta-thematic findings, the positive effects of the FCM are again predominant. When the post-complementary findings were examined, it was understood that the experiment group's success scores, where the FCM was used in the experimental dimension, were higher than those in the control group. That the positive codes regarding the model were at the forefront, after the participator opinions were asked for in thematic terms, shows that the FCM contributions were at a significant level in this stahe as they were in other stages. The results which were consistent with one another, supported and supplemented each other, following the examination of the effectiveness of the FCM in the two stages, and with four different types of analysis, contributed equally to the reliability of the research. In this context, with the integration of the results from both stages of the research, the deficiencies in one stage are eliminated, and completion is achieved, and the research will have a strong and comprehensive structure that includes rich data. In our current research, as stated in the suggestions presented for the more effective use of the FCM, the adaptation of learners to technology-supported applications in the age of technology can provide unlimited convenience when it comes to learning. For this reason, the contents of the applications to be used should be prepared according to the level of the student, and the number of students in the class should be arranged accordingly, in order to ensure that students use the technology efficiently. Furthermore, researchers are advised to use MCA to broaden the scope of their study, increase the richness of data, and achieve consistent and reliable results. This research is thought to contribute greatly to the literature as a result of its originality. 


\section{BIODATA and CONTACT ADDRESSES of AUTHORS}

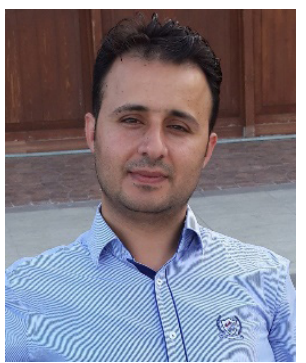

Dr. Tarik TALAN is an Assistant Professor in the department of computer engineering at Gaziantep Islam Science and Technology University. He has received the BSc degree in Department of Computer Education and Instructional Technology from Inonu University in 2005; MSc degree in Educational Technology from Suleyman Demirel University in 2014 and $\mathrm{PhD}$ degree from Istanbul University Informatics Department in 2018. His research areas include meta-analysis, meta-thematic analysis, blended learning, distance learning, human-computer interaction and use of social media in education. He has published his academic works in national and international journals.

\section{Tarik TALAN}

Department of Computer Engineering, Faculty of Engineering and Natural Sciences

Adress: Gaziantep Islam Science and Technology University, Gaziantep, TURKEY

Phone: + 0903429097500

e-mail: ttalan46@hotmail.com

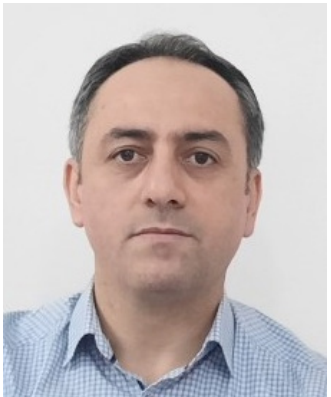

Dr. Veli BATDI is an Associate Professor of Gaziantep Education Faculty, Gaziantep University. Dr. Batdi gained his Ph.D. in Curriculum and Instruction at November, 2013. His academic interest areas are teaching principles and methods, curriculum development, teacher training, foreign language teaching, meta-analysis, multicomplementary approach, meta-thematic analysis, qualitative and quantitative research. He has many journal articles published in international indexes, and book chapters and other national and international articles, papers submitted to international meetings.

\section{Veli BATDI}

Curriculum and Instruction, Gaziantep Education Faculty

Address: Gaziantep University, 27000, Gaziantep, TURKEY

Phone: +905055048814

E-mail: velibatdi@gantep.edu.tr

\section{REFERENCES}

Akgun, M., \& Atici, B. (2017). The effect of flipped classroom on learners' academic achievements and views. Kastamonu Education Journal, 25(1), 329-344.

Alamri, M. M. (2019). Students' academic achievement performance and satisfaction in a flipped classroom in Saudi Arabia. International Journal of Technology Enhanced Learning, 11(1), 103-119.

Al-Harbi, S. S., \& Alshumaimeri, Y. A. (2016). The flipped classroom impact in grammar class on EFL Saudi secondary school students' performances and attitudes. English Language Teaching, 9(10), 60-80.

AlJaser, A. M. (2017). Effectiveness of using flipped classroom strategy in academic achievement and selfefficacy among education students of Princess Nourah Bint Abdulrahman University. English Language Teaching, 10(4), 67-77.

Atwa, Z. M., Din, R., \& Hussin, M. (2016). Effectiveness of flipped learning in physics education on Palestinian high school students' achievement. Journal of Personalized Learning, 2(1), 73-85.

Aydin, G. (2016). Ters yuz sinif modelinin universite ogrencilerinin programlamaya yonelik tutum, ozyeterlik algisi ve basarilarina etkisinin incelenmesi [The investigation of the effect of flipped classroom model on undergraduate students' attitude, self-efficacy and academic achievement towards programming]. (Master's Dissertation). DokuzEylul University, Izmir, Turkey. Available from the Council of Higher Education, National Dissertation Center, Dissertation ID:463358. 
Aydin, B., \& Demirer, V. (2017). A comprehensive analysis of the studies conducted in the framework of flipped classroom model. Educational Technology Theory and Practice, 7(1), 57-82.

Aydin, B. (2016). Ters yuz sinif modelinin akademik basari, odev/gorev stress duzeyi ve ogrenme transferi uzerindeki etkisi [The effects of flipped classroom model on academic achievement, homework/ task stress level and transfer of learning]. (Master's Dissertation). SuleymanDemirel University, Isparta, Turkey. Available from the Council of Higher Education, National Dissertation Center, Dissertation ID:429768.

Balikci, H. C. (2015). 'Flipped Classroom' modeliyle hazirlanan derse iliskin ogrenci goruslerinin ve ders basarilarinin degerlendirilmesi [Evaluation of the success of the lectures prepared with 'Flipped Classroom' model and students' opinion]. (Master's Dissertation). AfyonKocatepe University, Afyonkarahisar, Turkey. Available from the Council of Higher Education, National Dissertation Center, Dissertation ID:398596.

Banks, G. C., Kepes, S., \& Banks, K. P. (2012). Publication bias: The antagonist of meta-analytic reviews and effective policymaking. Educational Evaluation and Policy Analysis, 34(3), 259-277. DOI: $10.3102 / 0162373712446144$.

Batdi, V. (2018). Egitimde yeni bir yonelim: mega-coklu butuncul yaklasim ve beyin temelli ogrenme [A new trend in education: Mega-multi complementary approach and brain based learning]. IKSAD Publishing.

Batdi, V. (2017). Smart board and academic achievement in terms of the process of integrating technology into instruction: a study on the McA. Croatian Journal of Education, 19(3), 763-801. DOI: 10.15516/cje.v19i3.2542.

Batdi, V. (2019). Meta-tematik analiz [Meta-thematic analysis]. In V. Batdi (Ed.), Meta-tematik analiz: ornek uygulamalar [Meta-thematic analysis: sample applications]. (pp. 10-76). Ankara: Ani Publication.

Bergmann, J., \& Sams, A. (2012). Flip your classroom: Reach every student in every class every day. International Society for Technology in Education.

Bergstresser, M. B. (2018). Teaching students with dyslexia using the flipped classroom method. (Doctoral Dissertation). Northcentral University, USA.

Bishop, J. L., \& Verleger, M. A. (2013). The flipped classroom: A survey of the research, In ASEE National Conference Proceedings, Atlanta, GA (Vol. 30, No. 9, pp. 1-18).

Borenstein, M., Hedges, L.V., Higgins, J.P.T., Rothstein, H.R. (2009). Introduction to metaanalysis. West Sussex, UK: John Wiley \& Sons Ltd. ISBN: 978-0-470-05724-7

Borenstein, M., Hedges, L. V., Higgins, J. P. T., \& Rothstein, H. R. (2010). A basic introduction to fixedeffect and random-effects models for meta-analysis. Res. Syn. Meth., 1, 97-111.

Boyraz, S., (2014). Ingilizce ogretiminde tersine egitim uygulamasinin degerlendirilmesi [Evaluating flipped classroom/education method in English teaching]. (Master's Dissertation). AfyonKocatepe University, Afyonkarahisar, Turkey. Available from the Council of Higher Education, National Dissertation Center, Dissertation ID: 372445.

Bosner, S., Pickert, J., \& Stibane, T., (2015). Teaching differential diagnosis in primary care using an inverted classroom approach: student satisfaction and gain in skills and knowledge, BMC medical education, 15(1), 1-7.

Bulut, C. (2018). Tersyuz sinif modelinin EFL ogrenicilerinin gramer basarimlari uzerindeki etkisi: Sadece tersine cevirme degil, (Halihazirda) olanla butunlestirme [Impact of flipped classroom model on EFL learners' grammar achievement: Not only inversion, but also integration]. (Master's Dissertation). Yeditepe University, Istanbul, Turkey. Available from the Council of Higher Education, National Dissertation Center, Dissertation ID:508187. 
Card, N. A. (2012). Applied meta-analysis for social science research. New York: The Guilford Press.

Cashin, M. (2016). The effect of flipped classrooms on elementary students' reading scores. (Doctoral Dissertation). Northcentral University, USA.

Chao, C. Y., Chen, Y. T., \& Chuang, K. Y. (2015). Exploring students' learning attitude and achievement in flipped learning supported computer aided design curriculum: A study in high school engineering education. Computer Applications in Engineering Education, 23(4), 514-526.

Charles-Ogan, G., \& Williams, C. (2015). Flipped classroom versus a conventional classroom in the learning of mathematics. British Journal of Education, 3(6), 71-77.

Chen, Y., Wang, Y., \& Chen, N. S. (2014). Is FLIP enough? Or should we use the FLIPPED model instead?. Computers \& Education, 79, 16-27.

Cheng, L., Ritzhaupt, A. D., \& Antonenko, P. (2018). Effects of the flipped classroom instructional strategy on students' learning outcomes: a meta-analysis. Educational Technology Research and Development, 66(5), 1069-1086. https://doi.org/10.1007/s11423-018-9633-7.

Cheung, A. C., \& Slavin, R. E. (2013). The effectiveness of educational technology applications for enhancing mathematics achievement in K-12 classrooms: A meta-analysis. Educational research review, 9, 88-113.

Chu, L., \& Sun, S. H. (2015). The application of flipped classroom in pediatric physical therapy, Physiotherapy, 101, e252.

Cohen, J., Welkowitz, J., \& Ewen, R.E. (2000). Introductory statistics for the behavioral sciences. Orlando: Harcourt Brace College Publishers.

Clark, K. R. (2013). Examining the effects of the flipped model of instruction on student engagement and performance in the secondary mathematics classroom: An action research study. (Doctoral Dissertation). Capella University, USA.

Crawford, T. H. (2017). Flipped learning influence on active learning and assessments in the postsecondary hospitality classroom: An action research study. (Doctoral Dissertation). Capella University, USA.

Cumming, G. (2012). Understanding the new statistics: Effect sizes, confidence intervals, and metaanalysis. New York: Routledge.

Cakir, E. (2017). Ters yuz sinif uygulamalarinin fen bilimleri 7.sinif ogrencilerinin akademik basari, zihinsel risk alma ve bilgisayarca dusunme becerileri uzerine etkisi [The effect of flipped classroom on 7 th grade students' academic achievement, cognitive risk taking skills and computational thinking skills in science education classroom]. (Master's Dissertation). Ondokuz Mayis University, Samsun, Turkey. Available from the Council of Higher Education, National Dissertation Center, Dissertation ID:456600.

Davies, R. S., Dean, D. L., \& Ball, N. (2013). Flipping the classroom and instructional technology integration in a college-level information systems spreadsheet course. Educational Technology Research and Development, 61(4), 563-580.

Dixon, K. (2017). The effect of the flipped classroom on urban high school students' motivation and academic achievement in a high school science course. (Doctoral Dissertation). Liberty University, USA.

Duffy, C. M. (2016). The impact of flipped learning on student achievement in an eighth grade earth science classroom. (Doctoral Dissertation). Wilkes University, USA.

Dusenbury, M., \& Olson, M. (2019). The impact of flipped learning on student academic performance and perceptions. The Collegiate Aviation Review International, 37(1), 19-44.

Duval, S., \& Tweedie, R. (2000). Trim and fill: A simple funnel-plot-based method of testing and adjusting for publication bias in meta-analysis. Biometrics, 56(2), 455-463. 
Ekmekci, E. (2014). Harmanlanmis ogrenme odakli tersten yapilandirilmis yazma sinifi modeli [Flipped writing class model with a focus on blended learning]. (Doctoral Dissertation). Gazi University, Ankara, Turkey. Available from the Council of Higher Education, National Dissertation Center, Dissertation ID:356650.

Elian, S. M., \& Hamaidi, D. A. H. (2018). The effect of using flipped classroom strategy on the academic achievement of fourth grade students in Jordan. International Journal of Emerging Technologies in Learning (iJET), 13(02), 110-125.

Elliott, J. (1991). Action research for educational change. Bukhingam: Open University Press.

Enfield, J. (2013). Looking at the impact of the flipped classroom model of instruction on undergraduate multimedia students at CSUN. Techtrends: Linking Research \& Practice to Improve Learning, 57(6), 14-27.

Erdem Cavdar, O. (2018). Tersyuz sinif yaklasiminin geleneksel Ingilizce dersi ile butunlestirilmesi [Integrating flipped classroom approach into traditional English class]. (Master's Dissertation). Karadeniz Technical University, Trabzon, Turkey. Available from the Council of Higher Education, National Dissertation Center, Dissertation ID:508195.

Esteves J., \& Pastor J. (2004). Using a multimethod research approach to research enterprise systems implementations. Electronic Journal of Business Research Methods (EJBRM), 69-81.

Fadol, Y., Aldamen, H., \& Saadullah, S. (2018). A comparative analysis of flipped, online and traditional teaching: A case of female Middle Eastern management students. The International Journal of Management Education, 16(2), 266-280.

Files, D. D. (2016). Instructional approach and mathematics achievement: an investigation of traditional, online, and flipped classrooms in College Algebra. (Doctoral Dissertation). Central Florida University, USA.

Foldnes, N. (2016). The flipped classroom and cooperative learning: Evidence from a randomised experiment. Active Learning in Higher Education, 17(1), 39-49.

Fraga, L. M., \& Harmon, J. (2014). The flipped classroom model of learning in higher education: An investigation of preservice teachers' perspectives and achievement. Journal of Digital Learning in Teacher Education, 31(1), 18-27.

Fulton, K. (2012). Upside down and inside out: Flip your classroom to improve student learning. Learning \& Leading with Technology, 39(8), 12-17.

Gilboy, M. B., Heinerichs, S., \& Pazzaglia, G. (2015). Enhancing student engagement using the flipped classroom, Journal of Nutrition Education and Behavior, 47(1), 109-114.

Glass, G. V. (1976). Primary secondary and meta-analysis of research. Educational Researcher, 5(10), 3-8.

Gokdas, I., \& Gursoy, S. (2018). The effect of flipped classroom model on academic achievement and motivation in maths lesson at primary schools. Mediterranean Journal of Educational Research, 12(26), 159-174.

Guven Demir, E. (2018). Tersyuz sinif modeline dayali uygulamalarin ilkokul 4.sinif ogrencilerinin akademik basari ve planlama becerilerine etkisi [Effect of applications based on flipped classroom on academic achievement and planning skills of 4th grade primary school students]. (Doctoral Dissertation). OndokuzMayis University, Samsun, Turkey. Available from the Council of Higher Education, National Dissertation Center, Dissertation ID:519317.

Halili, S. H., \& Zainuddin, Z. (2015). Flipping the classroom: what we know and what we do not. The Online Journal of Distance Education and e-Learning (TOJDEL), 3(1), 28-35.

He, W., Holton, A., Farkas, G., \& Warschauer, M. (2016). The effects of flipped instruction on out-of-class study time, exam performance, and student perceptions. Learning and Instruction, 45, 61-71. 
Hedges, L. V. (1982). Estimation of effect size from a series of independent experiments. Psychological Bulletin, 92, 490-499. DOI:10.1037/0033-2909.92.2.490.

Heredia, K. (2015). The effects of the flipped classroom model on student academic growth in flipped and traditional community college classrooms. (Doctoral Dissertation). Aurora University, USA.

Hew, K. F., \& Lo, C. K. (2018). Flipped classroom improves student learning in health professions education: a meta-analysis. BMC medical education, 18(1), 38.

Hibbard, L., Sung, S., \& Wells, B. (2016). Examining the effectiveness of a semi-self-paced flipped learning format in a college general chemistry sequence. Journal of Chemical Education, 93, 24-30. http:// digitalcommons.auctr.edu/scpubs/16

Howell, D. (2013). Effects of an inverted instructional delivery model on achievement of ninth-grade physical science honors students. (Doctoral Dissertation). Gardner-Webb University, USA.

Hung, H. (2015). Flipping the classroom for English language learners to foster active learning, Computer Assisted Language Learning, 28(1), 81-96.

Iyitoglu, O. (2018). Ters yuz sinif modelinin Ingilizceyi yabanci dil olarak ogrenen ogrencilerin akademik basarilari, tutumlari ve ozyeterlik inanclari uzerindeki etkisi: Bir karma yontem calismasi [The impact of flipped classroom model on EFL learners' academic achievement, attitudes and selfefficacy beliefs: A mixed method study]. (Doctoral Dissertation). Yildiz Technical University, Istanbul, Turkey. Available from the Council of Higher Education, National Dissertation Center, Dissertation ID:491434.

Johnson, D. (2012). Power up!: Taking charge of online learning, Educational Leadership, 70(3), 84-85.

Kara, C. O. (2016). Tip fakultesi klinik egitiminde ters yuz sinif modeli kullanilabilir mi? [Can flipped classroom model be used in clinical education program of medical faculty?]. (Master's Dissertation). Akdeniz University, Antalya, Turkey. Available from the Council of Higher Education, National Dissertation Center, Dissertation ID:424655.

Karakurt, L. (2018). Lisans egitiminde B1 seviyesi icin yabanci dil olarak Ingilizce ogrenim siniflarina ters-yuz edilmis ve harmanlanmis dilbilgisi ogretimi [Flipped and blended grammar instruction for B1 level EFL classes at tertiary education]. (Master's Dissertation). Hacettepe University, Ankara, Turkey. Available from the Council of Higher Education, National Dissertation Center, Dissertation ID:516091.

Kelly, P. E., Polanin, J. R. Jang, S. J., \& Johnson, B. R. (2015). Religion, Delinquency, and Drug Use: A Meta-Analysis. Criminal Justice Review, 40(4), 505-523. DOI: 10.1177/0734016815605151.

Kurt, G. (2017). Implementing the flipped classroom in teacher education: Evidence from Turkey. Journal of Educational Technology \& Society, 20(1).211-221.

Lee, A. M. (2016). An examination of student outcomes and student satisfaction in a flipped learning environment: A quasi-experimental design. (Doctoral Dissertation). Nevada University, USA.

Leo, J., \& Puzio, K., (2016). Flipped instruction in a high school science classroom. Journal of Science Education and Technology, 25(5), 775-781.

Lipsey, M. W., \& Wilson, D. B. (2001).Practical meta-analysis. Thousand Oaks, CA:Sage.

Margosian, K. (2018). Examining the effect of flipped learning on english language learner mathematics achievement. (Master's Dissertation). California State University, USA.

Mason, G. S., Shuman T. R., \& Cook, K. E., (2013).Comparing the effectiveness of an inverted classroom to a traditional classroom in an upper-division engineering course, IEEE Transactions on Education, 56(4), 430-435.

McKay, J. A. (1992). Professional development through action research. Journal of Staff Development, $13(1), 18-21$. 
Millard, E. (2012). 5 Reasons Flipped Classrooms Work, University Business, p.26-29.

Miles, M. B., \& Huberman, A. M. (1994).Qualitative data analysis: An expanded sourcebook. Thousand Oaks, California: Sage.

Miller, R. (2005). Philosophical sources of holistic education. Journal of Values Education, 3(10), 33-40.

Milman, N. (2012). The flipped classroom strategy: What is it and how can it be used?. Distance Learning, 9(3), 85-87.

Missildine, K., Fountain, R., Summers, L., \& Gosselin, K. (2013). Flipping the classroom to improve student performance and satisfaction. Journal of Nursing Education, 52(10), 597-599.

Mok, H. N. (2014). Teaching tip: The flipped classroom. Journal of Information Systems Education, 25(1), 7-11.

Molnar, K. K. (2017). What effect does flipping the classroom have on undergraduate student perceptions and grades?. Education and Information Technologies, 22(6), 2741-2765.

Morgan, H., McLean, K., Chapman, C., Fitzgerald, J., Yousuf, A., \& Hammoud, M. (2015). The flipped classroom for medical students, The Clinical Teacher, 12(3), 155-160.

Mori, Y., Omori, M., \& Sato, K. (2016). The impact of flipped online Kanji instruction on written vocabulary learning for introductory and intermediate Japanese language students. Foreign Language Annals, 49(4), 729-749.

Nederveld, A., \& Berge, Z. L. (2015). Flipped learning in the workplace. Journal of Workplace Learning, 27(2), 162-172. DOI: 10.1108/JWL-06-2014-0044.

O'Flaherty, J., \& Philips, C. (2015). The use of flipped classrooms in higher education: A scoping review. Internet and Higher Education, 25, 85-95.

Olakanmi, E. E. (2017). The effects of a flipped classroom model of instruction on students' performance and attitudes towards chemistry. Journal of Science Education and Technology, 26(1), 127-137.

Onwuegbuzie, A. J., \& Dickinson, W. B. (2008). Mixed methods analysis and information visualization: Graphical display for effective communication of research results. The Qualitative Report, 13(2), 204-225.

Orwin, R. G., \& Vevea, J. L. (2009). Evaluating coding decisions. In H. Cooper, L. V. Hedges, \& J. C. Valentine (Eds.), The handbook of research synthesis and meta- analysis (2nd ed., pp. 177-203). New York: Russell Sage Foundation.

Overmyer, G. R. (2014). The flipped classroom model for college algebra: Effects on student achievement. (Doctoral Dissertation). Colorado State University, USA.

Pinto, C., \& Little, G., (2014). Flipped librarians: Assessing our own need to understand our users. The Journal of Academic Librarianship, 2(40), 192-193.

Prefume, Y. E. (2015). Exploring a flipped classroom approach in a Japanese language classroom: A mixed methods study. (Doctoral Dissertation). Baylor University, USA.

Presti, C. R. (2016). The flipped learning approach in nursing education: A literature review. Journal of Nursing Education, 55(5), 252-257. DOI: 10.3928/01484834-20160414-03.

Qader, R. (2017). Donusturulmus sinif egitiminin Ingilizce ogrenimi goren Irakli ogrencilerin yazma becerileri uzerindeki etkileri [The effect of flipped classroom instruction on Iraqi EFL learners' writing skills]. (Master's Dissertation). Gaziantep University, Gaziantep, Turkey. Available from the Council of Higher Education, National Dissertation Center, Dissertation ID:488654.

Relman, A. S. (1980). New reports of medical meetings: how reliable are abstracts? New England Journal of Medicine, 303, 277-278. DOI: 10.1056/NEJM198007313030509. 
Roehl, A., Reddy, S. L., \& Shannon, G. J. (2013). The flipped classroom: An opportunity to engage millennial students through active learning. Journal of Family and Consumer Sciences, 105(2), 44-49.

Rosenthal, R. (1979). The file drawer problem and tolerance for null results. Psychological Bulletin, 86(3), 638-641.

Rothstein, H. R., Sutton, A. J., \& Borenstein, M. J. (2006). Publication bias in meta-analysis, Chapter 1. In H. R. Rothstein, A. J. Sutton, \& M. Borenstein (Eds.), Publication bias in meta-analysis: Prevention, assessment and adjustments (pp. 1-7). Chichester, England: John Wiley and Sons, Ltd.

Russel, B. (1912). The philosophy of the truth. Retrieved from https://www.andrew.cmu.edu/user/kk3n/ epistclass/russell-rescher.pdf

Rutkowski, J., \& Moscinska, K. (2013). Self-directed learning and flip teaching: electric circuit theory case study. 41st SEFI Conference, Leuven, Belgium.

Saglam, D. (2016). Ters-yuzsinif modelinin Ingilizce dersinde ogrencilerin akademik basarilarina ve tutumlarina etkisi [The effect of flipped classroom model on the academic achievements and attitudes of students in English language teaching]. (Master's Dissertation).BulentEcevit University, Zonguldak, Turkey. Available from the Council of Higher Education, National Dissertation Center, Dissertation ID:451810.

Saunders, J. (2014). The flipped classroom: Its effect on student academic achievement and critical thinking skills in high school mathematics. (Doctoral Dissertation). Liberty University, USA.

Segumpan, L. L. B., \& Tan, D. A. (2018). Mathematics performance and anxiety of junior high school students in a flipped classroom. European Journal of Education Studies, 4(12), 1-33.

Sengel, E. (2014). Using the "Flipped classroom" to enhance physics achievement of the prospective teacher impact of flipped classroom model on physics course. Journal of the Balkan Tribological Association, 20(3), 488-497.

Sezer, B. (2017). The effectiveness of a technology-enhanced flipped science classroom. Journal of Educational Computing Research, 55(4), 471-494.

Shachar, M. (2002). Differences between traditional and distance learning outcomes: A meta-analytic approach. (Doctoral Dissertation). Touro University, USA.

Sharpe, E. H. (2016). An investigation of the flipped classroom in algebra two with trigonometry classes. (Doctoral Dissertation). Regent University, USA.

Sirakaya, D. A., (2015). Ters yuz sinif modelinin akademik basari, oz - yonetimli ogrenme hazir bulunuslugu ve motivasyon uzerine etkisi [The effect of flipped classroom model on academic achievement, self - directed learning readiness and motivation]. (Doctoral Dissertation).Gazi University, Ankara, Turkey. Available from the Council of Higher Education, National Dissertation Center, Dissertation ID:419422.

Sletten, S. R. (2015). Investigating flipped learning: Post-secondary student selfregulated learning, perceptions, and achievement. (Doctoral Dissertation). North Dakota University, USA.

Staker, H., \& Horn, M. (2012). Classifying K-12 blended learning, Innosight Institute. Retrieved from http://files.eric.ed.gov/fulltext/ED535180.pdf

Stone, B. B. (2012, May). Flip your classroom to increase active learning and student engagement. In Proceedings from 28th Annual Conference on Distance Teaching \& Learning, Madison, Wisconsin, USA.

Strayer, J. F. (2009). Inverting the classroom: A study of the learning environment when an intelligent tutoring system is used to help students learn. Saarbrucken: VDM Verlag Muller. 
Talan, T. (2018). Donusturulmus sinif modeline gore e-ogrenme ortaminin tasarimi ve modelin uygulanabilirliginin degerlendirilmesi [Design of e-learning environment according to flipped classroom model and evaluation of model applicability].(Doctoral Dissertation). Istanbul University, Istanbul, Turkey. Available from the Council of Higher Education, National Dissertation Center, Dissertation ID:534135.

Talan, T., \& Gulsecen, S. (2018). Ters-yuz sinif ve harmanlanmis ogrenmede ogrencilerin oz-duzenleme becerilerinin ve oz-yeterlik algilarinin incelenmesi [Evaluation of the students' self-regulation skills and perceived self-efficacy in flipped classroom and blended learning environments]. Turkish Journal of Computer and Mathematics Education (TURCOMAT), 9(3), 547-564. DOI: $10.16949 /$ turkbilmat. 403618

Talan, T., \& Gulsecen, S. (2019). The effect of a flipped classroom on students' achievements, academic engagement and satisfaction levels. Turkish Online Journal of Distance Education, 20(4), 31-60.

Tarazi, N. (2016). The influence of the inverted classroom on student achievement and motivation for learning in secondary mathematics in the United Arab Emirates: A quasi-experimental study. (Doctoral Dissertation). Northcentral University, USA.

Thai, N. T. T., De Wever, B., \& Valcke, M. (2017). The impact of a flipped classroom design on learning performance in higher education: Looking for the best "blend" of lectures and guiding questions with feedback. Computers \& Education, 107, 113-126.

Thalheimer, W., \& Cook, S. (2002). How to calculate effect sizes from published research articles: A simplified methodology. Retrieved from http://education.gsu.edu/coshima/EPRS8530/Effect_ Sizes_pdf4.pdf.

Thoms, C. L. (2012). Enhancing the blended learning curriculum by using the" flipped classroom" approach to produce a dynamic learning environment. In 5th International Conference on Education, Research and Innovation (pp. 2150-2157).

Touchton, M., (2015). Flipping the classroom and student performance in advanced statistics: Evidence from a quasi-experiment, Journal of Political Science Education, 11(1), 28-44.

Tucker, B. (2012). Online instruction at home frees class time for learning, Education Next, 12(1).

Turan, Z. (2015). Ters yuz sinif yonteminin degerlendirilmesi ve akademik basari, bilissel yuk ve motivasyona etkisinin incelenmesi [The evaluation of flipped classroom method and examination of its effects on academic achievement, cognitive load and motivation]. (Doctoral Dissertation). Ataturk University, Erzurum, Turkey. Available from the Council of Higher Education, National Dissertation Center, Dissertation ID:394794.

Vang, Y. V. (2017). The impact of the flipped classroom on high school mathematics students' academic performance and self-efficacy. (Doctoral Dissertation). California State University, USA.

Viera, A. J., \& Garrett, J. M. (2005). Understanding interobserver agreement: The kappa statistic. Family Medicine, 37(5), 360-363.

Voltz, E. A. (2016). Is flipped instruction in the string class an effective teaching strategy?. (Doctoral Dissertation). Trevecca Nazarene University, USA.

Webb, M., \& Doman, E. (2016). Does the flipped classroom lead to increased gains on learning outcomes in ESL/EFL contexts?. CATESOL Journal, 28(1), 39-67.

Wilson, D. B. (2009). Systematic coding. In H. Cooper, L. V. Hedges, \& J. C. Valentine (Eds.), The handbook of research synthesis and meta-analysis (2nd ed., pp. 159-176). New York: Russell Sage Foundation.

Wiginton, B. L. (2013). Flipped instruction: An investigation into the effect of learning environment on student self-efficacy, learning style, and academic achievement in an Algebra I classroom. (Doctoral Dissertation). University of Alabama Libraries, USA. 
Yavuz, M. (2016). Ortaogretim duzeyinde tersyuz sinif uygulamalarinin akademik basari uzerine etkisi ve ogrenci deneyimlerinin incelenmesi [An investigation into the effects of flipped classroom applications on the academic success and experiences of the students at secondary school]. (Master's Dissertation). Ataturk University, Erzurum, Turkey. Available from the Council of Higher Education, National Dissertation Center, Dissertation ID:429617.

Yildirim, A., \& Simsek, H. (2013). Sosyal bilimlerde nitel arastirma yontemleri [Qualitative research methods in social sciences]. Seckin Publishing, Ankara, Turkey.

Yildiz, S. N., Sarsar, F., \& Cobanoglu Ates, A., (2017). A literature review of flipped classroom practices, Electronic Journal of Social Sciences, 16(60), 76-86.

Yildiz, D. G. (2016). Effect of the flipped classroom on prospective teachers's academic achievement, metacognitive awareness and epistemological beliefs.Celal Bayar University Journal of Social Sciences, 14(3).405-426.

Yurtlu S. (2018). Fen egitiminde ters yuz sinif modelinin ogrenci basarisina ve goruslerine etkisinin incelenmesi [Effect of the flipped classroom model on student's achievement and views in science education]. (Master's Dissertation). MusAlparslan University, Mus, Turkey. Available from the Council of Higher Education, National Dissertation Center, Dissertation ID:506022.

Zhonggen, Y., \& Guifang, W. (2016). Academic achievements and satisfaction of the clicker-aided flipped business english writing class. Journal of educational technology \& society, 19(2), 298-312. 


\section{APPENDIX}

\section{Cappa Values}

\begin{tabular}{|c|c|c|c|c|c|c|c|c|c|c|c|c|c|c|c|c|c|c|c|}
\hline & \multicolumn{4}{|c|}{ Personal Dimension } & \multicolumn{6}{|c|}{ Learning Process } & \multicolumn{4}{|c|}{$\begin{array}{c}\text { Sensorial } \\
\text { Dimension }\end{array}$} & \multicolumn{5}{|c|}{ General Contributions } \\
\hline & \multicolumn{4}{|c|}{$\mathrm{K} 2$} & \multicolumn{5}{|c|}{$\mathrm{K} 2$} & \multicolumn{5}{|c|}{$\mathrm{K} 2$} & \multicolumn{5}{|c|}{ K2 } \\
\hline \multirow{4}{*}{$\bar{\Sigma}$} & & + & - & $\Sigma$ & & & + & - & $\Sigma$ & & & + & - & $\Sigma$ & & & + & - & $\Sigma$ \\
\hline & + & 26 & 2 & 28 & $\bar{x}$ & + & 28 & 3 & 31 & $\bar{x}$ & + & 23 & 2 & 25 & $\bar{x}$ & + & 21 & 1 & 22 \\
\hline & - & 3 & 16 & 19 & & - & 4 & 19 & 23 & & - & 2 & 16 & 18 & & - & 2 & 15 & 17 \\
\hline & $\Sigma$ & 29 & 18 & 47 & & $\Sigma$ & 32 & 22 & 54 & & $\Sigma$ & 25 & 18 & 43 & & $\Sigma$ & 23 & 16 & 39 \\
\hline \multicolumn{5}{|c|}{ Kappa: .777 p:.000 } & \multicolumn{5}{|c|}{ Kappa: .733 p:.000 } & \multicolumn{5}{|c|}{ Kappa: .809 p:.000 } & \multicolumn{5}{|c|}{ Kappa:.843 p:.000 } \\
\hline \multicolumn{5}{|c|}{ NegativeAspects } & \multicolumn{5}{|c|}{ Suggestions } & \multicolumn{5}{|c|}{ PositiveAspects } & \multicolumn{5}{|c|}{$\begin{array}{c}\text { Exp. } \\
\text { NegativeAspects }\end{array}$} \\
\hline \multicolumn{5}{|c|}{$\mathrm{K} 2$} & \multicolumn{5}{|c|}{$\mathrm{K} 2$} & \multicolumn{5}{|c|}{$\mathrm{K} 2$} & \multicolumn{5}{|c|}{$\mathrm{K} 2$} \\
\hline \multirow{4}{*}{$\bar{x}$} & & + & - & $\Sigma$ & & & + & - & $\Sigma$ & & & + & - & $\Sigma$ & & & + & - & $\Sigma$ \\
\hline & + & 17 & 2 & 19 & $\bar{x}$ & + & 11 & 1 & 12 & $\bar{x}$ & + & 25 & 4 & 29 & $\bar{x}$ & + & 23 & 1 & 24 \\
\hline & - & 0 & 12 & 12 & & - & 1 & 7 & 8 & & - & 3 & 19 & 22 & & - & 3 & 16 & 19 \\
\hline & $\Sigma$ & 17 & 14 & 31 & & $\Sigma$ & 12 & 8 & 20 & & $\Sigma$ & 28 & 23 & 51 & & $\Sigma$ & 26 & 17 & 43 \\
\hline \multicolumn{5}{|c|}{ Kappa: .868 p:.000 } & \multicolumn{5}{|c|}{ Kappa: .792 p:.000 } & \multicolumn{5}{|c|}{ Kappa: .722 p:.000 } & \multicolumn{5}{|c|}{ Kappa: .809 p:.000 } \\
\hline
\end{tabular}

